\title{
Lisabonos sutarties poveikis ES bendrai saugumo ir gynybos politikai
}

\begin{abstract}
Lisabonos sutartis - reikšmingiausias XXI a. pirmojo dešimtmečio ES dokumentas. Be būtinų įtvirtinti procedūrinių ir institucinių Sajungos funkcionavimo reikalavimų po didžiausios jos plètros $2004 \mathrm{~m}$. (prièmus 10 naujų valstybių) ir $2007 \mathrm{~m}$. sąrašą papildžius dar dviem, Sutartis papildoma ir ilgą laiką diskusijų objektais buvusiomis bendros saugumo ir gynybos politikos naujovèmis. ES bendra užsienio ir saugumo politika tampa ES savarankiškos politikos teisinio subjektiškumo dalimi ir žymi ES gebëjimą veikti nepriklausomai nuo valstybių narių (BUSP sutartimi įtvirtinama daugiau nei tik valstybių narių interesų suma). Ši efektyvumą, ilgalaikiškumą ir veiksmingumą įtvirtinanti nuostata žymi galimybę ES tarptautinëje arenoje kalbèti „,vienu balsu“ ir taip sustiprinti savo, kaip tarptautinio saugumo veikèjo, ivaizdị. Negana to, Lisabonos sutartyje pirmą kartą atskiru skyriumi pateikiama bendra saugumo ir gynybos politika (BSGP), apibréžiama kaip sudedamoji operacinio pobūdžio BUSP dalis. Šalia šių pakeitimu Lisabonos sutartimi atsiranda ir kitų institucinių naujovių: Europos Vadovų Tarybos (EVT) pirmininkas, Europos Sajungos vyriausiasis igaliotinis užsienio reikalams ir saugumo politikai, Išorès veiksmų tarnyba bei Europos gynybos agentūra. Tad pagrindinis straipsnio tikslas yra atsakyti į klausimą, ar ir kaip Sutartyje įtvirtintos naujovès veda link giluminių bendros saugumo ir gynybos politikos problemų sprendimo. Siekiant tą padaryti, analizuojama po Lisabonos sutarties pasikeitęs ES statusas, būtina įtvirtinti jos strateginè vizija, naujai apibrèžta institucinė struktūra. Dėmesys sutelkiamas į svarbiausias bendros saugumo ir gynybos politikos problemas: kariniu pajègumų trūkumą, finansavimo neefektyvumą bei į kontroversiškai vertinamas „naujoves“ - solidarumo bei bendros gynybos sąlygas.
\end{abstract}

\section{Ivadas}

Dabartinè Europos Sajunga, atšventusi penkiasdešimtąsias susikūrimo metines, daugumos jos nariu gyventojų vis dar suvokiama kaip ekonominio bendradarbiavimo organizacija. Ir tik nedaugelis susimąsto apie tai, kad dabartinės ES susikūrimą lèmė saugumo motyvas. 1947 m. Diunkerko ir 1948 m. Briuselio sutartimis siekta „sukurti saugumo bendruomenę, neleisiančią kilti ateities karams Vakaru Europoje“ ${ }^{1}{ }^{1}$ Galimai šios saugumo bendruomenès idejją turëjusi vainikuoti gynybos sajunga, tiesa, žlugo, bežengdama pirmuosius

\footnotetext{
* Dr. Margarita Šešelgytè - Vilniaus universiteto Tarptautinių santykių ir politikos mokslų instituto direktoriaus pavaduotoja. Adresas korespondencijai: Vokiečiu g. 10, 01130 Vilnius, tel. (8 5) 2514132, el. paštas: margarita.seselgyte@tspmi.vu.lt. Indré Lelevičiūtè - Vilniaus universiteto Tarptautinių santykiu ir politikos mokslų instituto magistrantė. Adresas korespondencijai: Vokiečiu g. 10, 01130 Vilnius, tel. (8 5) 2514130, el. paštas: indre.leleviciute@gmail.com ${ }^{1}$ Howorth J., European integration and defense: the ultimate challenge? Chaillot paper, 43. Paris: WEU Institute for security studies, 2000, p. 1.
} 
žingsnius, ir kuriam laikui saugumo dėmuo ES nunyko. Tik dešimto dešimtmečio pradžioje saugumo ir gynybos klausimai vèl sugrįžo atgal ị ES interesu lauką. Mastrichto sutartimi įsteigta ES trijų ramsčių struktūra apèmè ir bendros užsienio ir saugumo politikos (toliau - BUSP) dimensiją².

Visgi dar iki diskusijų dèl Mastrichto sutarties buvo aišku, kad politinio bendradarbiavimo rẻmuose išlaikyti ribą tarp užsienio politikos reikalų ir su saugumu susijusių aspektų bus sunku. 1981 m. tuometinės ES valstybės sutarè, kad Europos politinio bendradarbiavimo srityje gali būti aptariami ir su valstybių saugumu susiję klausimai. ${ }^{3}$ Tačiau politinio bendradarbiavimo veiklu plètra buvo labai lèta, praktiškai apsiribota tik deklaratyviais pareiškimais. Taigi šaltojo karo metu atskiras forumas Europos saugumo problemoms svarstyti ir spręsti nebuvo sukurtas. Tai nulėmė keletas priežasčių: visų pirma, Europa nenorejjo skatinti įtampos santykiuose su JAV, taip pat baiminosi netekti NATO saugumo garantiju, ir pagaliau - norejo išlaikyti neginčijamą suverenitetą nacionalinių karinių pajègu panaudojimo klausimu. ${ }^{4}$ Pasibaigus šaltajam karui, susidarè palanki aplinka Europos Sajungos savarankiškos saugumo politikos plètotei. Mastrichto sutartimi antrajame ramstyje buvo įtraukta bendra užsienio ir saugumo politika, tačiau ES gynybos politika išliko Vakarų Europos Sajungos (VES) kompetencijoje, ${ }^{5}$ kurios veikla buvo visiškai inkorporuota i NATO sistemą. Kiek daugiau savarankiškumo saugumo srityje Europos Sajunga igavo 1994 m., sukūrus Europos saugumo ir gynybos identiteto (ESGI) NATO viduje koncepciją. ${ }^{6}$ Visgi tai buvo tik ribotas savarankiškumas: naudojami pajègumai buvo ",atskiriami, tačiau ne atskirti“" (angl. separable but not separate) nuo NATO. O tai ne tik nesustiprino VES savarankiškumo, tačiau netgi dar labiau susiejo ją su NATO

Europos saugumo ir gynybos politikos (toliau - ESGP) ${ }^{8}$ plètotè pajudèjo pirmyn tik 1998 m., po Jungtinès Karalystès ir Prancūzijos vadovų susitikimo Saint-Malo mieste. Šio susitikimo metu buvo susitarta įtraukti Vakarų Europos Sajungos organizacijos funkcijas į ESGP. Baigiamojoje susitikimo deklaracijoje

\footnotetext{
${ }^{2}$ Sutartyje teigiama, kad BUSP itraukia visus klausimus, susijusius su Sajungos saugumu, iskaitant ir galiausiai siekiamą sukurti bendrą gynybos politiką, kuri vestu prie bendros gynybos. The Treaty of Maastricht, Article J.4.

${ }^{3}$ Trevor Salmon, Alistair Sheperd,Toward a European army: a military power in the making? Boulder: Lynne Rienner publishers, 2003, p. 29.

${ }^{4}$ John Peterson, Helene Sjursen, A common foreign policy for Europe: competing visions of the CFSP. New York: Routledge, 1998, p. 95.

${ }^{5}$ Christopher Piening, Global Europe: the European Union in world affairs. Boulder; Lynne Rienner publishers, 1997, p. 42.

${ }^{6}$ Jolyon Howorth, John Keller, Defending Europe: the EU, NATO and the quest for European autonomy. New York: Palgrave Macmillan, 2003, p. 8.

${ }^{7}$ Stephen Gomersall, "NATO and European defense". Perceptions. Journal of International Affairs, March-May 1999, Volume IV, Number 1. http://www.sam.gov.tr/perceptions/Volume4/March-May1999/ gomersall.PDF

${ }^{8}$ Europos saugumo ir gynybos politika (ESGP) Lisabonos sutartyje keičiama į Bendrają saugumo ir gynybos politiką (BSGP). Treaty of Lisbon, 42 article. Official journal of the European Union, C 83, Volume 53, 2010 March 30. http://eur-lex.europa.eu/LexUriServ/LexUriServ.do?uri=OJ:C:2010:083:FULL:EN:P DF [žiūrèta $2010 \mathrm{~m}$. balandžio 28 d.]
} 
tvirtinama: „Sajunga privalo turèti galimybę atlikti savarankiškas operacijas, paremtas patikimais kariniais pajėgumais, priemonėmis, spręsti dẻl jų panaudojimo ir pasirengimu tą daryti, reaguojant iz tarptautines krizes" ${ }^{\prime 9} 2001 \mathrm{~m}$. Europos Vadovu Tarybos Lakeno susitikimo metu ESGP paskelbta veikiančia. ${ }^{10}$ Tačiau po šiu gana rimtų postūmių aktyvesnè ESGP plètotė vẻl sustojo keleriems metams. Visgi nepaisant šio sustojimo ES ESGP sferoje nuo paskelbimo veikiančia įvykdè ne vieną karinę operaciją, kuri buvo pripažinta sėkminga. Kai kurie žinomi šios srities mokslininkai linkę optimistiškai žiūrèti į ESGP plètotės galimybes: pavyzdžiui, Paulas Cornishas ir Geoffrey Edwardsas ${ }^{11}$ tvirtina, kad ES politinè valia ir fiziniai pajègumai ją vis labiau igalina aktyviai naudoti karines priemones. Jolyon'as Howorthas laikosi nuomonės, jog nacionaliniai nesutarimai kariniu priemonių (pajėgumų) naudojimo klausimu tarp valstybių narių mažẻja ir jos vis labiau yra linkusios sutikti su tuo, kad ES, igyvendindama savo tikslus už savo sienu, privalo pasitelkti ir karinius pajejgumus. ${ }^{12}$ Taigi, nors vieningos nuomonės dèl to, kas užkirto kelią tolesniems žingsniams ESGP srityje - praktiniai ESGP funkcionavimo elementai ar politiniai ES valstybiu narių nesutarimai - nėra, akivaizdu, kad egzistuoja keletas probleminių bloku, kurių neišsprendus tolesnis ESGP likimas lieka neaiškus.

Pirmajam blokui galima priskirti Jolyono Howortho iškeltas problemas, stabdančias Europos bendros gynybos kūrimą - organizacinės struktūros trūkumus ir nepakankamus karinius išteklius. ${ }^{13}$ Julianas Lindley-French'as šalia institucinių problemų mini ir Europos Sajungos narių tarpusavio nesutarimus. ${ }^{14}$ Karinių pajègumu problemą ivardija ir F. S. Berenskoetteris. ${ }^{15}$ Karinių pajègumų trūkumo, institucinio nepasirengimo ir politinių nesutarimų problemos dažnai yra minimos ir praktiku, dirbančiu su Europos Sajungos klausimais tiek ES, tiek nacionalinèse institucijose, pasisakymuose. Šios problemos dar labiau išryškëja ekonominès krizės ir bendrų diskusijų dèl ES ateities kontekste. Antraji problemini bloką sudaro klausimai, susiję su strateginio požiūrio trūkumu ES išorès veiksmuose. Pajègumai gali būti išplètojami, institucijos - sukurtos, tačiau tolesniam ESGP progresui būtinas strateginis požiūris ir stipri politinė valia. Būtent politinès valios trūkumas dažnai yra įvardijamas kaip pagrindinė

\footnotetext{
${ }^{9}$ Franco - British summit. Joint declaration on European Defense, 1998 http://www.atlanticcommunity. org/Saint-Malo\%20Declaration\%20Text.html [žiūrèta 2010m. balandžio 12d.]

${ }^{10}$ Leaken European Council Presidency Conclusions. (2001). Leaken. http://ec.europa.eu/governance/ impact/background/docs/goteborg_concl_en.pdf [žiūrèta $2010 \mathrm{~m}$. balandžio $12 \mathrm{~d}$.]

${ }^{11}$ Cornish P., Edwards G., „The Strategic Culture of the European Union: a Progress Report”. International Affairs, 81 (4). London, Royal Institute of International Affairs: Blackwell. 2005

${ }^{12}$ Howorth J., ,European Defence and Changing politics of the European Union: Hanging together or hanging separately?" Journal of Common Market Studies, 39 (4), 2001.

${ }^{13}$ Lindley -French J., „St Malo II: Rescuing European Defence”. Institute for Public Policy Research,

Volume 9, Issue 4. p. 217.

${ }^{14}$ Lindley - French J. cituojamas Rynning, S., „The European Union: Towards a Strategic Culture?"Security Dialogue, 6 (4). Oslo: International Peace Research Institute: SAGE Publications. 2003, p. 480.

${ }^{15}$ Berenskoetter, F. S., „Mapping the Mind Gap: A Comparison of US and European Security Strategies”. Security Dialogue, 36 (1). SAGE Publications. 2005. p. 87.
} 
bendros saugumo ir gynybos politikos problema. Vienos ES valstybès narès neįsitraukia į ES vykdomas misijas ir kariniu pajėgumų plètojimą dèl to, kad bijo kompromituoti santykius su NATO, kitos nepatenkintos disproporciniu ESGP misiju finansavimo mechanizmu, kada gaunama nauda neproporcinga valstybių indèliui, trečios tiesiog pasižymi siauresniu saugumo politikos kursu ar yra neutralios ${ }^{16}$ (tai natūraliai atbaido jas nuo bendrų veiksmų). Bet koks Sajungos neveiksnumas saugumo ir gynybos politikoje dažnai aiškinamas bendros politinès valios stoka, nenoru būti įtakingam ar imtis vadovavimo (nes nepakankami kariniai ir finansiniai resursai), nenoru prisiimti išlaidas ir riziką. Taigi, nors diskusijos apie šias ESGP kamuojančias problemas nėra naujos, Lisabonos sutartis, pasiūliusi svarbių ir ilgai lauktų naujovių saugumo srityje (naujas skyrius, skirtas saugumo politikai, bendros gynybos ir solidarumo sąlygos, struktūrizuoto bendradarbiavimo galimybè $)^{17}$, leidžia iš naujo įvertinti šių problemų aktualumą. O tai, kad dèl šių svarbių naujovių nekilo didelių diskusiju, leidžia įtarti, kad valstybès narès yra pasiryžusios žengti žingsnị pirmyn kurdamos bendrą Europos Sąungos saugumo ir gynybos politiką.

Lisabonos sutartis neabejotinai yra vienas iš reikšmingiausių dokumentų ES integracijos istorijoje. Viena vertus, ji įtvirtina naują institucinę išsiplètusios ES konsteliaciją, antra, joje neregėtai daug dėmesio yra skiriama ES bendrai užsienio ir saugumo politikai, anksčiau likdavusiai ES sutarčių „paraštèse". ES Saugumo studijų instituto vadovas Alvaras Vasconselos'as, įsigaliojus Lisabonos sutarčiai, pažymëjo, kad ši sutartis suteikia daug vilčių bendrai užsienio ir saugumo politikai, pabrèždamas, kad pagaliau valstybės narès „gebès kalbėti vieningai“" ${ }^{18}$ Ir nors tikrą Lisabonos sutartimi įtvirtintų pokyčiu reikšmę dar sudètinga vertinti, daug kas priklausys nuo "gyvosios praktikos", tačiau neįmanoma nepastebèti vien to fakto, kad Lisabonos sutartyje pirmą kartą Bendra saugumo ir gynybos politika (toliau - BSGP $)^{19}$ aprašoma atskirame jai skirtame skyriuje. Šiame skyriuje įtvirtinama didžioji dalis vadinamajame „Šokoladiniame vadovų susitikime ${ }^{\text {"20 }}$ pasiūlytų ir į Sutartį dèl Konstitucijos Europai įtrauktų naujovių: bendros gynybos ir solidarumo sąlygos, institucinès

\footnotetext{
${ }^{16}$ Marcin Terlikowksy, „European army - an ultimate tool for ESDP?“. Eurasia Critis. Eurasia Inteligence \& Strategies. http://eurasiacritic.co.uk/articles/european-army-ultimate-tool-esdp [žiūrėta $2010 \mathrm{~m}$. balandžio $15 \mathrm{~d}$.]

${ }^{17}$ Tiesa, verta prisiminti, kad Lisabonos sutartimi įtvirtintos naujovès ESGP srityje taip pat nèra visai naujos - jos jau buvo pristatytos Sutartyje dèl Konstitucijos Europai. Tačiau referendumai Nyderlanduose ir Prancūzijoje sustabdè Sutartyje dèl Konstitucijos siūlomus pokyčius ESGP dar keleriems metams.

${ }^{18}$ Vasconselos A., „After Lisbon: the States of the Union“. ISSUES, 2010 March, No. 31, EU Institute for Security Studies.

${ }^{19} \mathrm{BSGP}$ - bendra saugumo ir gynybos politika (nauja sąvoka, keičianti Europos saugumo ir gynybos politiką).

${ }^{20}$ Šokoladinis vadovų susitikimas (angl. chocolate summit) - $2003 \mathrm{~m}$. balandžio 29 d. Briuselyje įvykęs keturių šalių (Belgijos, Liuksemburgo, Prancūzijos ir Vokietijos) vadovų susitikimas dèl bendradarbiavimo gynybos srityje. Šio susitikimo metu pasiūlytos kontroversiškos naujovės susilaukė daug kritikos iš euroskeptikų britų ir JAV, kurie susitikimą ,,pakrikštijo“ šokoladiniu, apeliuodami ị tai, kad šiose šalyse yra gaminamas šokoladas. Howorth J., „Part II: The Other Option: An Autonomous Europe, The Euro - Atlantic Security Dilemma: France, Britain and the ESDP”. Journal of Transatlantic Studies, 3 (1). Edinburgh University Press, p. 51.
} 
struktūros pakitimai, karinių pajėgumų plètotės esminiai klausimai. Straipsnyje siekiama išanalizuoti Lisabonos sutartimi įtvirtintus pokyčius ES saugumo ir gynybos politikos srityje bei įvertinti šiu pokyčių reikšmę tiek ESGP pagrindinių problemų sprendimui, tiek bendrai ESGP tolesnei plètotei.

\section{Solidarumo ir bendros gynybos sąlygu reikšmè ir taikymas}

Solidarumo ir bendros gynybos sąlygos - ko gero, įdomiausios Lisabonos sutarties naujovès saugumo ir gynybos politikos srityje saugumo organizaciju tyrinėtojams. Tiek viena, tiek kita yra susijusi su ES narių įsipareigojimu imtis veiksmų vienos ar kelių ES narių labui, pastarosioms susidūrus su saugumo problema. Bendrų veiksmų įsipareigojimas - lyg aliuzija į NATO 5 ir 6 straipsnius - gali sudaryti įspūdi, kad Europos Sajunga tampa gynybine sajunga su įsipareigojimais ir garantijomis gynybos srityje. Viena vertus, tai turètų bent iš dalies patenkinti tas valstybes nares, kurios kritikavo ES dèl jos nesugebejjimo suteikti tvirtas saugumo garantijas lyginant ją su NATO, kita vertus, nuraminti tas, kurios tvirtino, kad ES yra nepajègi kovoti su svarbiausiomis XXI a. saugumo grèsmèmis.

Solidarumo sąlyga ispanų siūlymu pirmą kartą paminėta Konstitucinëje sutartyje. Tai buvo natūralus ispanų žingsnis po teroristinių išpuolių Madride. Tada globalios kovos su terorizmu kontekste Europos Sajunga be didesnių diskusijų šį siūlymą parèmé. Konstitucinėje sutartyje minima solidarumo sąlyga numate pagalbą ES valstybėms narėms ar trečiosioms valstybėms (vyriausybiu prašymu) teroristinio išpuolio ar gamtinės katastrofos atveju. ${ }^{21}$ Lisabonos sutartis iš esmès atkartoja Konstitucinės sutarties nuostatas: „Sajunga ir valstybės narès veikia bendrai ir solidariai, jei kuri nors valstybė narè patirtų teroro aktą, gaivalinę nelaimę ar žmogaus sukeltą katastrofą. Sajunga sutelkia visas savo turimas priemones, įskaitant valstybių narių jos dispozicijon perduotus karinius išteklius, siekdama: užkirsti kelią terorizmo grèsmei valstybiu narių teritorijose; apsaugoti demokratines institucijas ir civilius gyventojus nuo galimo teroro akto; teroro aktą patyrusiai valstybei narei teikti pagalbą jos teritorijoje jos politinės valdžios institucijų prašymu; ir gaivalinę nelaimę ar žmogaus sukeltą katastrofą patyrusiai valstybei narei teikti pagalbą jos teritorijoje jos politinès valdžios institucijų prašymu. “22 Straipsniuose, apibrėžiančiuose solidarumo sąlygos taikymą, yra aiškus imperatyvas, t.y. kad susidarius konkrečiai situacijai, valstybės narès privalo nukentëjusiai valstybei teikti pagalbą. Numatoma ir tai,

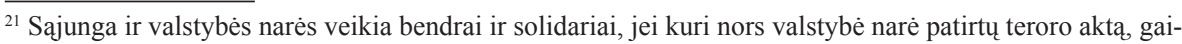
valinę nelaimę ir žmogaus sukeltą katastrofą“. The Treaty Establishing Constitution for Europe, Chapter VIII, Article III - 329.1.

${ }^{22}$ Treaty of Lisbon, 222 article.
} 
kad pagalbai gali būti naudojamos įvairios priemonės. Ir nors Lisabonos sutartyje nèra aiškios nuorodos į kariniu pajėgumų naudojimą taikant solidarumo sąlygą, jų naudojimas nėra ir apribotas. Vis dèlto, šios sąlygos taikymas yra gana ribotas, t.y. apsiriboja tokiais atvejais, kaip teroristiniai išpuoliai Madride ar Londone, ir yra daugiau atsakomoji priemonè. Viena iš svarbiausiu kovos su terorizmu strategijos daliu - prevencija - dažnai yra susijusi su trečiosiomis šalimis. Kariniu pajègumų naudojimas taikant solidarumo sąlygą trečiosiose valstybėse yra gana problemiškas, jis nėra aiškiai apibrèžtas. Taip pat lieka neaišku ir tai, ar taikant solidarumo sąlygą yra įmanomi prevenciniai kariniai veiksmai kovojant su terorizmo grèsme. Todèl, panašu, kad artimiausiu metu ši sąlyga išlieka daugiau deklaratyvaus pobūdžio, parodanti, kad ES nori kovoti su viena svarbiausių XXI a. grẻsmiu - terorizmu -ir sudaro galimybes ES šalims bent jau simboliškai išreikšti solidarumą nukentëjusioms ES narèms. Tai, kad sprendimai dèl solidarumo sąlygos taikymo priimami vienbalsiai Taryboje, taip pat rodo, kad ji bus taikoma tik labai išimtinemis sąlygomis - atvejais, kai egzistuos aiškus konsensusas. Šios sąlygos taikymo ribas išplèsti padètų ES, kaip tarptautinio veikèjo, aiškios strategijos sukūrimas, tačiau, kaip ir daugelyje su saugumo ir užsienio politika susijusių ES iniciatyvu, čia susiformuoja „,užburto rato" problema: dèl interesų skirtumo ES valstybès narès nèra linkusios sukurti vientisos tarptautiniu veiksmu strategijos, o pastarosios nebuvimas lemia tai, kad šių skirtingų interesų neįmanoma suderinti.

Kita Lisabonos sutartimi ịtvirtinama naujovè - bendros gynybos sąlyga, kuri yra kiekvieno karinio aljanso esminè sąlyga. Iš esmès ši sąlyga (nors netiesiogiai) ES nèra nauja. Žlugus Europos gynybos sajungos idèjai penktajame dešimtmetyje, bendros gynybos nuostatos buvo ịtvirtintos modifikuotoje Briuselio sutartyje, kurioje teigiama, kad karinio užpuolimo atveju valstybės narės teiks viena kitai pagalbą, pasiremdamos JT 51 str. ${ }^{23}$ Taigi dalis ES nariu jau nuo penktojo dešimtmečio pabaigos buvo susaistytos ne tik NATO 5 str., bet ir modifikuotos Briuselio sutarties ịsipareigojimais. Tačiau ši sutartis negalioja naujosioms ES narėms, todėl iš jų pusės dažnai buvo galima išgirsti kaltinimu, esą jos pasigendą dabartinėse ES sutartyse bendrą gynybą numatančių straipsnių ir dėl to savo saugumą linkusios sieti išimtinai su NATO. Kaip atsakas į šią kritiką bendros gynybos principas buvo pasiūlytas jau Sutartyje dèl Konstitucijos Europai, o vèliau numatytas ir Lisabonos sutartyje. Bendros gynybos sąlyga numato, kad: „Jei valstybė narė patiria karinę agresiją savo teritorijoje, kitos valstybės narės, vadovaudamosi Jungtinių Tautu Chartijos 51 str., jos atžvilgiu yra ịpareigotos jai teikti visokeriopą įmanomą pagalbą ir paramą. ${ }^{24}$ Taigi įsigaliojus Lisabonos sutarčiai atsiranda imperatyvas ES narėms ginti nukentèjusią nuo karinès agresijos narę visokeriopomis priemonėmis, tačiau lieka neaišku, ar yra imperatyvas ginti karinemis priemonemis ir, jei tokio imperatyvo nèra, kada jos gali būti panaudojamos? Problema yra tai, kad ES dalyvavimo karinėse misijose patirtis rodo, kad karines priemones ES

\footnotetext{
${ }^{23}$ Brussels Treaty, http://www.weu.int/Treaty.htm [žiūrèta 2010 m. liepos 12d.]

${ }^{24}$ Treaty of Lisbon, 42.7 article.
} 
geba panaudoti tik tada, kai egzistuoja aiškus politinis konsensusas įsitraukti į misiją, ir jei tikètina, jog misijos baigtis bus sẻkminga. Dẻl ribotų karinių išteklių tokių misijų sąrašas labai sutrumpejja. Kyla klausimas, ar tos pačios problemos neištiks karinių operaciju, inicijuotų pagal bendros gynybos sąlygą?

Dar vieną problemą, susijusią su bendros gynybos sąlygos apibrèžimu ir galinčią paralyžiuoti šios sąlygos veikimą, galima įžvelgti Lisabonos sutarties 42.7 straipsnio antrojoje dalyje. Joje teigiama, kad valstybės narès įsipareigoja padèti nuo karinės agresijos nukentëjusiai ES narei, tačiau jei tai „nepažeidžia kai kurių valstybių narių saugumo ir gynybos politikos specifikos" arba jei „bendradarbiavimas šioje srityje atitinka narystès Šiaurès Atlanto sutarties organizacijoje įsipareigojimus, o Šiaurès Atlanto sutarties organizacija išlieka valstybiu, kurios yra jos narès, kolektyvinès gynybos pagrindu ir jos igyvendinimo forumu“25. Tokiu būdu yra bandoma apsaugoti neutralias ES nares bei nuraminti proatlantinès pozicijos besilaikančias ES valstybes. Tačiau yra ir kita problema - naujosios ES narès NATO gynybos garantijas renkasi ne tiek dèl 5 str., kiek dèl JAV politinès paramos ir kariniu garantijų. Bandyti ginčytis ar paneigti šią tiesą nèra prasmès. Taigi akivaizdu, kad nors Lisabonos sutartis ir kelia teorinių aliuzijų dèl savarankiškos gynybos, praktiškai pagrindine saugumą laiduojančia organizacija daugumai ES narių vis tiek išlieka NATO.

ES bendros gynybos sąlygos „,aptakumą“ kritikuoja G. Quille’is, tvirtindamas, kad siekiant sutarimo tarp valstybių narių buvo pasiektas susitarimas, tenkinantis daugybę išskirtinumų, taigi galintis apriboti šios sąlygos taikymo galimybes. ${ }^{26}$ Dẻl šių kelių pasirinkimo variantų tampa akivaizdu, kad ES atsakas, jei jos valstybė narè patirtų agresiją savo teritorijoje, nebus vieningas ir sutartinis. O tai kelia abejonių dèl bendros gynybos sąlygos igyvendinimo. Panašu, kad tiek bendros gynybos, tiek solidarumo sąlygų taikymo galimybès priklausys visu pirma nuo to, ar valstybėms narèms pavyks susitarti dèl ES atsako tiek į terorizmo iššūkius, tiek į karinę agresiją gairių ir veikimo priemonių: ar šios priemonės gali būti karinès, jei taip - tai kokiais atvejais, ir ar ES yra pajègi atsakyti į iššūkius savo turimais kariniais resursais. Tačiau, net ir nustačius aiškias gaires, dèl vieningo ES strateginio mąstymo trūkumo tikètina, kad kiekvienas šių sąlygų taikymo atvejis susilauks diskusijų Taryboje.

\section{Bendros saugumo ir gynybos politikos statuso pasikeitimas}

Vienas iš svarbiausių Lisabonos sutarties elementų - instituciniai pokyčiai, susiję su užsienio ir saugumo politika. Visų pirma, ES igyja teisinị

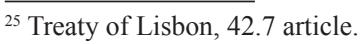

${ }^{26}$ Quille G., ,The Lisbon Treaty and its Implication for CFSP/ESDP”. Directorate- General for External Policies, Policy Department, p. 8. http://www.luhan.ro/docs/Lisbon_Treaty_implications_CFSP_ ESDP_2009.pdf [žiūrèta $2010 \mathrm{~m}$. balandžio 20 d.]
} 
subjektiškumą ${ }^{27}$, nyksta trijų ramsčių sistema, o Sajungos išorès veiksmams vadovauja, t.y. išorès veiksmų įvairiose srityse nuoseklumą užtikrina naujai patvirtintas Europos Sajungos vyriausiasis igaliotinis užsienio reikalams ir saugumo politikai (toliau - ESVI) ${ }^{28}$. Europos saugumo ir gynybos politika (ESGP) Lisabonos sutartyje yra pervadinama bendra saugumo ir gynybos politika (BSGP).

Naujame sutarties skirsnyje, pavadintame „Konkrečios nuostatos dèl bendros užsienio ir saugumo politikos " ${ }^{\text {"29 }}$ BSGP yra įvardijama kaip sudedamoji BUSP dalis, užtikrinanti Sajungos operaciniam veiksnumui reikalingus civilinius ir karinius pajègumus, kuriais Sajunga gali naudotis vykdydama misijas už Sajungos ribu, skirtas taikos palaikymui, konfliktų prevencijai, tarptautinio saugumo stiprinimui laikantis Jungtinių Tautų Chartijos principų. ${ }^{30}$ Jame pabrěžiama, kad BSGP yra sudedamoji, daugiau operacinio pobūdžio BUSP dalis, taigi neišvengiamai susijusi su tolesne BUSP plètote bei BUSP teisinio statuso pakitimu. BUSP, kaip ES savarankiškos politikos teisinio subjektiškumo atsiradimas, reiškia ES gebejjimą veikti nepriklausomai nuo valstybių nariu, pasiremiant Sajungos institucijomis, t.y. kad BUSP, o kartu ir BSGP, kaip jos sudedamoji dalis, yra formuojama ES mastu ir tampa kažkuo daugiau nei tik valstybių narių interesu suma. Ši naujovè suteikia ES teisinius igaliojimus „,kalbėti“ ES vardu tarptautinëje politikoje. Jei šią sutarties nuostatą pavyktų igyvendinti praktikoje, tai neabejotinai reikštų revoliucinį postūmį BUSP ir BSGP plètotëje tiek suteikiant galimybes formuoti strateginę politikos ir veiksmų vizija, kurios anksčiau nebuvo, tiek imantis kitų valstybėse narèse nepopuliarių sprendimu, pavyzdžiui, bendro ES vadovaujamo valstybių narių karinių pajėgumų planavimo. Šią nuostatą sutvirtina ir tai, kad prioritetų formavimas BUSP, įsigaliojus Lisabonos sutarčiai, tampa ESVI ir Tarybos užduotimi (valstybès nebetenka pirmininkavimo ES Tarybai suteikiamų galių šioje srityje). Iš pirmo žvilgsnio šių BUSP efektyvumą, nuoseklumą ir ilgalaikiškumą galimai užtikrinsiančių veiksmų negalima vertinti vienareikšmiškai. Nepaisant kompetenciju perskirstymo, valstybės narès išlieka pagrindinės sprendimų prièmėjos BUSP. Pagrindinė institucija, brėžianti strategines BUSP gaires, tebėra Taryba (bei Vadovu Taryba ypač svarbiais klausimais $)^{31}$, kurioje pagrindiniu smuiku toliau groja valstybės narès. Todèl ir tolesni žingsniai užpildant Lisabonos sutarties straipsnius konkrečiu turiniu priklausys nuo pastarujų konsensuso ir politinės valios.

Verta pažymèti tai, kad tarsi siekiant pasilikti galimybę žengti žingsni atgal, Lisabonos sutartimi yra įvedamas saugiklis, ribojantis potencialų ES galių augimą valstybių narių suverenumo sąskaita. Lisabonos sutarties deklaracija Nr. 24 pabrèžia, kad ES teisinis subjektiškumas reiškia tik tiek, jog ji veikia ne-

\footnotetext{
${ }^{27}$ Treaty of Lisbon, Declaration concerning the legal personality of the European Union, Official journal of the European Union. C83, Volume 53, 2010 March 30, p. 346.

${ }^{28}$ Treaty of Lisbon, 21.3 article.

${ }^{29}$ Naujos BUSP institucijos, itvirtintos Lisabonos sutartimi: EVT pirmininkas, Europos Sajungos vyriausiasis igaliotinis užsienio reikalams ir saugumo politikai; Išorès ryšių tarnyba, Europos gynybos agentūra.

${ }^{30}$ Treaty of Lisbon, 42 article.

${ }^{31}$ Treaty of Lisbon, 26 article.
} 
peržengdama jai valstybių narių susitarimu Sutartimi suteiktų kompetencijos ribų. ${ }^{32}$ Taigi, nors BUSP ir BSGP statuso pakitimas yra rimtas žingsnis link vieningos ES užsienio, saugumo ir gynybos politikos, valstybès narès pasilieka ne tik teisę kontroliuoti kintantị galių balansą tarp valstybių ir ES kompetencijos šioje srityje, bet ir išlaiko galimybę užkirsti kelią tolesniems pokyčiams, jei paaiškètu, kad tokiems žingsniams neužteks politinès valios.

\section{ES tarptautinio vaidmens strateginè vizija}

Sajungos veiksmai BUSP srityje dažniausiai būna reakcija į konkretų įvyki, o ne nuoseklios ES interesų analizès rezultatas. Visos iki šiol vykdytos ES misijos buvo organizuotos ad hoc principu, reaguojant i labai skirtingas problemas ir pasirenkant įvairius geografinius regionus (iš 25 ES vykdytų misijų net penkios vyko Kongo Demokratinèje Respublikoje, o ne mažiau probleminiame Pietų Kaukazo regione - tik 2) ${ }^{33}$. Panašu, kad dažniausiai ES misijos pradžią vienoje ar kitoje pasaulio vietoje lemdavo politiniai valstybių narių interesai, turimi pajègumai bei tikètina misijos baigtis (kai sąmoningai siekiama pasirinkti politiškai mažiausiai jautrius bei potencialiai labiausiai sėkmingus operacijų prasme pasaulio taškus). Šie sporadiški ES veiksmai nesiderina su stipraus tarptautinių santykių veikëjo saugumo srityje įvaizdžiu ir verčia abejoti, ar ES tikrai siekia bei nori juo tapti. Todèl BSGP kritikai dažnai tvirtina, kad Europos Sajungai yra reikalinga aiškiai suformuluota ir ES mastu visuotinai pripažinta strateginė koncepcija, fiksuojanti bent tris esminius ES karinès dimensijos tolesniam vystymui dalykus: kaimynystės politiką, santykius su NATO ir, trečia, ES, kaip globalaus veikejjo, funkcijų apibrèžimą.

Vieningos ES, kaip tarptautinių santykių veikëjo ar saugumo veikëjo, strategijos trūkumą buvo bandyta pašalinti patvirtinant Europos saugumo strategiją (ESS) ${ }^{34}$ ir vèliau bandant ją patikslinti 2008 2003 m. priimtoje Europos saugumo strategijoje (ESS) ${ }^{36}$ bendrais bruožais buvo siekiama apibrèžti pagrindines ES karinių priemonių naudojimo gaires. Tačiau dẻl valstybių išsiskyrusių interesų pavyko suformuoti tik labai aptakų dokumentą, nenurodantį nei konkrečiu strateginių ES interesu, nei, kas ypač aktualu BSGP, kaip ES įsivaizduoja karinę galią ir karinių priemonių naudojimą. Net pačioje strategijoje buvo pripažinta, kad ES trūksta valstybes nares vienijančio vardiklio,

\footnotetext{
${ }^{32}$ Schmidt J., „Common Foreign and Security Policy and European Security and Defence Policy after the Lisbon Treaty: old problems solved?", p. 247.

${ }^{33}$ Overview of the missions and operations of the European Union, September 2010. http://www.consilium.europa.eu/showPage.aspx?id=268\&lang=en [žiūrèta $2010 \mathrm{~m}$. balandžio $29 \mathrm{~d}$.]

${ }^{34}$ A Secure Europe in a Better World: European Security Strategy. Brussels, 12 December, 2003. http:// www.consilium.europa.eu/uedocs/cmsUpload/78367.pdf [žiūrèta $2010 \mathrm{~m}$. balandžio $20 \mathrm{~d}$.]

${ }^{35}$ Report on the implementation of European Security Strategy - Providing Security in a Changing World. Brussels, 11 December 2008. S407/08. http://www.consilium.europa.eu/ueDocs/cms_Data/docs/pressdata/EN/reports/104630.pdf [žiūrèta $2010 \mathrm{~m}$. balandžio 20 d.]

${ }^{36}$ European Security Strategy: a Secure Europe in a Better World.
} 
kuris skatintu pastarąsias aktyviai naudoti ES karines priemones, ${ }^{37}$ o tai reiškia, kad ES neturi bendro tarptautinių santykių veikëjo identiteto, kurio pagrindu formuotųsi bendri ES interesai.

Dar vienas svarbus bendros strateginès vizijos trūkumo aspektas, ypač aktualus BSGP tolesnei plètotei - tai, kad regionų ir operaciju, kuriuose naudojamos karinès ar civilinès priemonès, pobūdis lemia konkrečiu pajègumu plètotę. ES atveju, kai trūksta strateginès vizijos ir sutarimo, kur bei kada bus naudojami kariniai pajėgumai, neįmanoma atsakyti į klausimą, kokių pajègumu ES reikia? O tai savo ruožtu dar labiau komplikuoja ir taip problemini pajègumų klausimą. Bendros vizijos ir sutarimo problema tokiu būdu iš politinio strateginio lygmens prasiskverbia ir į kitus su kariniu priemonių naudojimu susijusius lygmenis - operacinį bei taktinį. Generolas Wesley Clarkas, prisimindamas karinę operaciją Kosove, teigè, kad tuo metu sprendimų prièmimo efektyvumas netgi operaciniu lygmeniu labai nukentëjo nuo išsiskyrusių ES nacionalinių interesų. ${ }^{38}$ Šalių narių nesutarimai situacijose, kai sprendimus reikia priimti ir reaguoti ypač greitai, rimtai kenkia tiek operacijos eigai, tiek rezultatams.

Nors Lisabonos sutartyje valstybės narès yra įpareigojamos užtikrinti Sajungos operaciniam veiksnumui reikalingus civilinius ir karinius pajėgumus, kuriais Sąjunga gali naudotis vykdydama misijas už Sajungos ribų ${ }^{39}$, laipsniškai tobulinti savo karinius pajègumus bei igyvendinti visas reikalingas priemones pramoninei ir technologinei gynybos sektoriaus bazei stiprinti, ${ }^{40}$ Lisabonos sutartis nepasiūlo ES išorès veiksmų strategijos, o karinių priemonių naudojimas išlieka neapibrèžtas. Tiesa, galimas gaires, kokiais atvejais gali būti naudojamos karinės priemonès, suteikia Petersbergo užduotys, ${ }^{41}$ kurios Lisabonos sutartyje yra išplečiamos ir detaliai aprašomos. ${ }^{42}$ Paminėtina, kad nuo $1992 \mathrm{~m}$. Petersbergo užduočių sąrašas plètėsi net keletą kartų reaguojant tiek į tarptautinės saugumo aplinkos pokyčius, tiek į ES ambicijų lygio kitimą (žr. 1 lentelę). Šalia jau anksčiau Amsterdamo sutartimi įtvirtintų humanitarinių ir gelbejjimo misiju bei koviniu pajėgu vykdomų krizių valdymo misijų ${ }^{43}$ Lisabonos sutartis dar itraukia bendrus nusiginklavimo veiksmus, karinio konsultavimo ir pagalbos, konfliktu prevencijos ir taikos palaikymo bei pokonfliktinio stabilizavimo užduotis. ${ }^{44}$ Petersbergo užduočių išplètimas ir fiksavimas Lisabonos sutartyje

\footnotetext{
${ }^{37}$ European Security Strategy: a Secure Europe in a Better World. p.11.

${ }^{38}$ Clarkas cituojamas: Rynning S., „The European Union: Towards a Strategic Culture?”Security Dialogue, 6 (4). Oslo: International Peace Research Institute: SAGE Publications. 2003, p. 487 - 488.

${ }^{39}$ Treaty of Lisbon, 42.1 article.

${ }^{40}$ Treaty of Lisbon, 42.3 article.

${ }^{41} 1992$ m. VES šalys pasirašè Petersbergo deklaracija, patvirtinančia jų pasiryžimą suformuoti karinius vienetus, skirtus Petersbergo užduotims igyvendinti, kurios buvo apibrèžtos kaip humanitarinès operacijos, gelbèjimo darbai, taikos palaikymas ir krizių valdymas. Vèliau šių užduočiu igyvendinimo atsakomybè su kitomis funkcijomis buvo perduota ES.

${ }^{42}$ Treaty of Lisbon, 43 article.

${ }^{43}$ The treaty of Amsterdam, Article J7.2, 1997 October $2^{\text {nd. }}$. http://www.eurotreaties.com/amsterdamtreaty. pdf [žiūrèta $2010 \mathrm{~m}$. balandžio 28 d.]

${ }^{44}$ Treaty of Lisbon, 43 article.
} 
padidina ES veikimo globalioje pasikeitusioje pasaulio aplinkoje galimybes (platesnis užduočių spektras garantuoja didesnę laisvę vykdant misijas) bei iš dalies nubrèžia galimas gynybos pajėgumu plètotès kryptis. Tačiau išlieka neaišku, kokiais atvejais ir kuriuose regionuose ES yra pasirengusi šias misijas vykdyti. Panašu, kad ir toliau, kol nebus suformuluota aiški ES tarptautinị vaidmenį apibrèžianti strategija, dalyvavimą vienoje ar kitoje misijoje lems „norinčių ir galinčių" tas misijas vykdyti valstybių nacionaliniai interesai.

\section{Lentelè. Petersbergo užduočių apibréžimo kaita}

\begin{tabular}{|c|c|c|}
\hline $\begin{array}{c}\text { Amsterdamo sutartis } \\
(1997 \mathrm{m.})\end{array}$ & $\begin{array}{c}\text { Galutinis tikslas } 2010 \\
\text { (2004 m.) }\end{array}$ & $\begin{array}{l}\text { Lisabonos sutartis } \\
\text { (2009 m.) }\end{array}$ \\
\hline $\begin{array}{ll}\text { - } & \text { Humanitarinès ir } \\
\text { - } & \text { gelbèjimo užduotys } \\
\text { Taikos palaikymo } \\
\text { misijos } \\
\text { - } \text { Koviniu pajejgu } \\
\text { vykdomos krizių } \\
\text { valdymo misijos, } \\
\text { iskaitant taikdarystę }\end{array}$ & $\begin{array}{ll}\text { - } & \text { Humanitarinès ir } \\
\text { gelbejimo misijos } \\
\text { Kovinių pajėgų } \\
\text { vykdomos misijos, } \\
\text { įskaitant taikdarystę } \\
\text { Bendri nusiginklavimo } \\
\text { veiksmai } \\
\text { Pagalba trečiosioms } \\
\text { šalims, kovojančioms } \\
\text { prieš terorizmą }\end{array}$ & $\begin{array}{ll}\text { - } & \text { Bendri nusiginklavimo } \\
\text { - } & \text { veiksmai } \\
\text { Humanitarinès ir } \\
\text { - } \quad \text { Kelbèjimo užduotys } \\
\text { Karinio konsultavimo ir } \\
\text { pagalbos operacijos } \\
\text { Konflikty prevencijos } \\
\text { ir taikos palaikymo } \\
\text { užduotys } \\
\text { Koviniụ pajejgu } \\
\text { vykdomos kriziu } \\
\text { valdymo misijos, } \\
\text { iskaitant taikdarystę } \\
\text { ir pokonfliktinio } \\
\text { stabilizavimo operacijas }\end{array}$ \\
\hline
\end{tabular}

Sudaryta autoriu, remiantis Amsterdamo sutartimi ${ }^{45}$, Galutiniu tikslu 2010 ${ }^{46}$, Lisabonos sutartimi ${ }^{47}$.

Pastaba. Užduotis buvo bandoma išplèsti tiek Europos saugumo strategijoje (ESS), tiek Sutartyje dèl Konstitucijos Europai (galiausiai nepriimtoje). Lisabonos sutartyje įtvirtintas Petersbergo užduočiu apibrėžimas toks pat kaip ir Sutartyje dèl Konstitucijos Europai. ${ }^{48}$ Kursyvu išskirtos tos išplèstos Petersbergo užduotys, kurios pirmą kartą įtvirtintos Lisabonos Sutartimi.

\footnotetext{
${ }^{45}$ The treaty of Amsterdam, 1997 October $2^{\text {nd }}$. http://www.eurotreaties.com/amsterdamtreaty.pdf [žiūrèta $2010 \mathrm{~m}$. balandžio $28 \mathrm{~d}$.]

${ }^{46}$ Headline Goal 2010, http://www.consilium.europa.eu/uedocs/cmsUpload/2010\%20Headline\%20Goal. pdf [žiūrèta $2010 \mathrm{~m}$. balandžio 28 d.]

${ }^{47}$ Treaty of Lisbon, Official journal of the European Union, C 83, Volume 53, 2010 March 30. http://eurlex.europa.eu/LexUriServ/LexUriServ.do?uri=OJ:C:2010:083:FULL:EN:PDF [žiūrèta $2010 \mathrm{~m}$. balandžio 28 d.]

${ }^{48}$ Treaty establishing a Constitution for Europe. Official journal of the European Union, C 310, Volume 47, 2004 December 16. http://eur-lex.europa.eu/JOHtml.do?uri=OJ:C:2004:310:SOM:en:HTML [žiūrèta $2010 \mathrm{~m}$. balandžio $28 \mathrm{~d}$.]
} 


\section{Institucinè BSGP struktūra įsigaliojus Lisabonos sutarčiai}

Lisabonos sutartis, siekiant supaprastinti BUSP valdymą, padaryti ji lankstesnį bei efektyvesnį, įtvirtino keletą svarbių pakitimų BUSP institucinejje struktūroje, kuri yra svarbi ir BSGP. Visu pirma, Lisabonos sutartis suskirstè BRIST (Bendrujų reikalų ir išorès santykių taryba), kuri buvo viena svarbiausių veikëju priimant sprendimus dèl BSGP, ic dvi atskiras tarybas: Bendruju reikalu ir Užsienio reikalų. ${ }^{49}$ Šis atskyrimas, tikètina, leis efektyviau organizuoti darbą, suteikiant daugiau laiko Užsienio reikalų tarybai užsiimti užsienio ir saugumo politikos klausimais, kurių apimtys pastaraisiais metais ES labai išaugo. Antra, šalia jau egzistavusių BUSP institucijų, Lisabonos sutartimi yra pasiūlomos naujos: EVT pirmininkas, Europos Sajungos vyriausiasis igaliotinis užsienio reikalams ir saugumo politikai, Išorès veiksmų tarnyba bei Europos gynybos agentūra (kuri kelerius metus jau veikè, bet nebuvo įtvirtinta sutartimi). ${ }^{50}$ Visgi nauju institucijų steigimas pats savaime nieko nereiškia. Verta detaliau patyrinèti jų funkcijas, galias BUSP bei galios balanso tarp valstybiu narių ir ES instituciju pokyti įsigaliojus Lisabonos sutarčiai.

Apskritai instituciniai Lisabonos sutarties pakitimai daugiausia yra susiję su išsiplètusiomis EVT ir Europos Sajungos vyriausiojo igaliotinio užsienio reikalams ir saugumo politikai (ESVİ) funkcijomis bei kompetencija. ESVI vykdo bendrą užsienio ir saugumo politiką kartu su valstybėmis narèmis, pasitelkdamas nacionalines ir Sajungos priemones; pirmininkauja Užsienio reikalų tarybai ir yra EK vicepirmininkas; savo pasiūlymais prisideda prie bendros užsienio ir saugumo politikos plètojimo bei užtikrina EVT ir ET priimtų sprendimų igyvendinimą; atstovauja Sajungai BUSP reikaluose, Sajungos vardu veda politinį dialogą su trečiosiomis šalimis ir išreiškia Sajungos poziciją tarptautinėse organizacijose ir tarptautinėse konferencijose. ${ }^{51}$ Taigi BSGP srityje pagrindinis ESVI darbas yra ne tik brèžti gaires, bet kartu su Taryba koordinuoti ES misijas ir atsakyti už juc igyvendinimą. ${ }^{52}$ Tačiau ESVI igaliojimų gausa ir atsakomybės dydis verčia užduoti keletą klausimų, susijusių su būsimu BSGP efektyvumu.

Visu pirma tai lojalumo ir atskaitomybės klausimas. ESVI yra ir EK vicepirmininkas, ir vyriausiasis igaliotinis. Kaip EK vicepirmininkas, jis yra atskaitingas EK pirmininkui, o kaip vyriausiasis igaliotinis - ET. Sutartyje šis klausimas lieka neatsakytas ir nèra aišku, kam įpareigotas atsiskaityti yra ESVI. Kadangi BUSP klausimais nesutarimų tarp šių dviejų instituciju praeityje yra kilę ne vienas, panašu, kad dabartinei vyriausiajai igaliotinei prireiks daug diplomatinių sugebėjimų siekiant konsensuso tarp Komisijos ir Tarybos. Antra, Jungtinės Karalystės Bendruomenių Rūmų Užsienio reikalų

\footnotetext{
${ }^{49}$ Treaty of Lisbon, 16.6 article.

${ }^{50}$ Treaty of Lisbon, $15 ; 18 ; 27 ; 45$ articles.

${ }^{51}$ Treaty of Lisbon, 26.3, 27.1, 27.2 articles.

52 Treaty of Lisbon, 30.2 articles.
} 
komiteto išplatintoje ataskaitoje teigiama, jog yra labai tikètina, kad kovojant dèl lojalumo vienai ar kitai institucijai ESVI pasirinkimas bus Taryba. Tokiu būdu Lisabonos sutartimi visos galios BUSP srityje yra sutelkiamos Tarybos rankose, ${ }^{53}$ t.y. pakeičiamas tarpinstitucinis balansas Tarybos, o ne Komisijos naudai. Tą tvirtina ir Wolfgangas Wesselsas, teigdamas, kad, palyginti su Nicos sutartimi, įsigaliojus Lisabonos sutarčiai galių balansas tarp Tarybos ir Komisijos BUSP pasikeičia Tarybos naudai. ${ }^{54}$ Galios balanso perskirstymą iliustruoja dar keletas pavyzdžių. Mastrichto sutartyje buvo įtvirtinta, kad EK disponuoja iniciatyvos BUSP teise ${ }^{55}$, be EK siūlymo ET negalėdavo priimti jokio sprendimo, o Lisabonos sutartimi tiesiogine iniciatyvos teise iš EK perduodama ESVI, kuriam taip pat suteikiama ir prerogatyva sušaukti neeilinị Tarybos posėdi. ${ }^{56}$ Viena vertus, tarpinstitucinio balanso pokytis išpildo su Lisabonos sutartimi susijusius lūkesčius padaryti BUSP efektyviau valdomą, t.y. įvairių funkcijų BUSP srityje, anksčiau išmėtytų tarp Komisijos ir BRIST, koncentravimas vienose ESVI rankose gali turèti ir teigiamų aspektų. Kita vertus, būtina nepamiršti, kad Taryboje pagrindiniai veikejjai yra valstybės, kurių nuomonès dažnai išsiskiria, kai nesutampa interesai. Kartais toks nuomonių išsiskyrimas svarbesniais klausimais gali rimtai paralyžiuoti BUSP, kaip tai atsitiko Irako karo metu 2003 m. W. Wesselsas tvirtina, kad Lisabonos sutartimi įsteigta Vyriausiojo igaliotinio pozicija yra komplikuota, per daug priklausanti nuo kitų instituciju, vykdanti per daug įvairių bei nepakankamai apibrèžtų užduočių ir turinti per mažai pagalbininku. ${ }^{57}$ Todèl panašu, kad ESVİ funkcijos bus daugiau derybininko ir politikos ígyvendinimo prižiūrètojo, o pagrindinėmis politikos formuotojomis išliks valstybės narès. Dabartinis ESVI ir jo tarnybos interesu ratas, kai siekiama koncentruotis ties ES diplomatinės tarnybos konstravimo ir Irano klausimais, daugeliu atveju pamirštant BSGP ir kitus BUSP aspektus, gali signalizuoti tiek apie politinès valios bei konsensuso tarp valstybiu nariu trūkumą šiais klausimais, tiek apie ESVI negebejjimą susidoroti su labai plačia BUSP darbotvarke.

Dar viena Lisabonos sutarties naujovè, iš pirmo žvilgsnio keičianti valstybių narių ir ES institucijų galios balansą - pirmininkavimo Užsienio reikalų tarybai perdavimas ESVI. Kitaip nei kitoms Taryboms, kurioms 18 mèn. laikotarpiu pirmininkauja iš anksto numatytos triju valstybiu nariu grupès, sudarytos lygios rotacijos tarp valstybių narių pagrindu, atsižvelgiant i jų įvairovę ir geografinę pusiausvyrą Sąjungoje, Užsienio reikalų tarybai pirmininkauja

\footnotetext{
${ }^{53}$ House of Common Foreign Affairs Committee. Foreign Policy Aspects of the Lisbon Treaty. Third report of the session 2007-2008, 20 p. http:/www.publications.parliament.uk/pa/cm200708/cmselect/ cmfaff/120/120.pdf [žiūrèta 2010 m. gegužès 5d.]

${ }^{54}$ Wessels W. and Bopp F., ,The Institutional Architecture of CFSP after the Lisbon Treaty- Constitutional breakthrough or challenges ahead?“. Challenge. Liberty \& Security. Research Paper No. 10, June 2008, p. 15.

${ }^{55}$ The Maastricht Treaty, Article 228a., Maastricht February $7^{\text {th }} 1992$. http://www.eurotreaties.com/maastrichtec.pdf [žiūrèta $2010 \mathrm{~m}$. balandžio 28 d.]

${ }^{56}$ Treaty of Lisbon, 30.2 articles.

${ }^{57}$ Wessels W., p. 23.
} 
nuolatinis atstovas - ESVI. ${ }^{58}$ Viena vertus, taip sudaromos galimybės užtikrinti ilgalaikiškesnę, nuoseklesnę bei efektyvesnę BUSP, kita vertus, įvertinus jau minètus galimus ESVI tarnybos iššūkius, šis perskirstymas gali lemti dar gilesnę stagnaciją probleminėse BUSP srityse. Ir nors gali atrodyti, kad pirmininkavimo funkcijų perdavimas ESVI yra ženklus galios balanso perskirstymas ES institucijų naudai valstybių narių sąskaita, nes valstybės narès nebeformuoja užsienio ir saugumo klausimų darbotvarkès, taip pat nebepirmininkauja šiose srityse vykstantiems posėdžiams, visgi nevertètų pamiršti dviejų darbotvarkès kontrolès mechanizmu, kuriuos valstybės narės išlaiko savo rankose. Visu pirma valstybės narès rašo tiek trejeto, tiek individualias pirmininkavimo programas, kuriose, nors ir derinant su ES institucijomis, atsispindès pagrindiniai užsienio, saugumo ir gynybos politikos klausimai. Antra, galutiniai sprendimai strateginiais ir politiniais klausimais šiose srityse bus priimami Užsienio reikalų taryboje ir Europos Vadovu Taryboje ${ }^{59}$. Todèl panašu, kad valstybès narès ir po Lisabonos sutarties įsigaliojimo tars lemiamą žodį BUSP bei BSGP plètotės klausimais bei formuos šias politikos kryptis.

Isigaliojus Lisabonos sutarčiai, apskritai išaugęs Europos Parlamento vaidmuo BUSP srityje iš esmès nesikeičia. Tiesa, Lisabonos sutartimi įtvirtinta, kad ESVI reguliariai konsultuojasi su EP svarbiausiais bendros užsienio ir saugumo politikos, bendros saugumo ir gynybos politikos aspektais, esminiais pasirinkimo klausimais ir informuoja apie šių politikos krypčių raidą; savo ruožtu EP gali teikti paklausimus ir rekomendacijas ET ir ESVI, o pažangos igyvendinant bendrą užsienio ir saugumo politiką, įskaitant bendrą gynybos ir saugumo politiką, svarstymai Parlamente padidinti nuo vieno iki dviejų svarstymų per metus. ${ }^{60}$ Vis dèlto visos naujos EP funkcijos yra konsultacinio pobūdžio. Tiesa, EP gali „kontroliuoti“ BUSP veiksmus, pasinaudodamas biudžeto kontrolès principu, tačiau BSGP atveju ir šios galimybės yra labai apribotos ${ }^{61}$, kadangi bendros ES išlaidos, kurios atsiranda dèl karinio ar gynybinio pobūdžio operaciju, yra finansuojamos valstybių narių pagal BVP dydį.

Vertinant Lisabonos sutartimi įtvirtintų institucinių BUSP pokyčių reikšmę BSGP, svarbu atkreipti dėmesi, kad jie yra susiję su bendromis BSGP gairèmis, jos galima strategine plètote, taip pat sprendimais dèl konkrečiu ES vykdomų misijų. Operaciniu lygmeniu arba politikos igyvendinimo lygmeniu gynybos srityje didelių pokyčių nèra. Viena svarbiausių institucijų BSGP, įtakos prasme gal net svarbesne už Užsienio reikalų tarybą, yra Politinis ir saugumo

\footnotetext{
${ }^{58}$ Treaty of Lisbon, „Declaration on Article 16(9) of the Treaty on European Union concerning the European Council decision on the exercise of the Presidency of the Council", 1 article.

${ }^{59}$ Europos Vadovų Taryba nustato BUSP, ịskaitant gynybinio pobūdžio reikalus, Sajungos strateginius interesus, tikslus ir apibrèžia bendras gaires, priima reikiamus sprendimus; kai dėl tarptautinès situacijos Sajungai reikia operatyviai veikti, reikalingus sprendimus taip pat priima Taryba (Treaty of Lisbon, 26 ir 28 articles).

${ }^{60}$ Treaty of Lisbon, 36 article.

${ }^{61}$ Treaty of Lisbon, 41 article.
} 
komitetas (toliau - PSK) ${ }^{62}$. Jo padèties ir galiu Lisabonos sutartis beveik nepakeitė, išskyrus tai, kad šis komitetas turès du „,̌̌eimininkus“: kolegialią Tarybą ir asmeninį ESVİ atstovą. Politinį ir saugumo komitetą sudaro valstybių narių atstovai, tad šiuo atžvilgiu ESVI, nors ir yra dalinis PSK ,„šeimininkas“, daugiau įtakos turès tik tada, kai tarpusavyje sutars valstybės. Tad įtakos svertai priversti valstybes nares susitarti net ir po Lisabonos sutarties įsigaliojimo išlieka per maži. Negalima nuvertinti ir vadinamojo "briuselizacijos" efekto ${ }^{63}$ - kai Briuselyje dirbantys ekspertai, diplomatai bei kariškiai turi konkrečiu tikslu ir yra suinteresuoti konsensusu, kurio siekia bandydami paveikti nuomones valstybėse narėse. Tai ypač svarbu srityse, reikalaujančiose ekspertinių žiniu, susijusių su politikos igyvendinimu. Tačiau „,briuselizacijos“ efektas veikia tik mažai politiškai jautriais klausimais, todèl neužtikrina svertų priversti valstybes susitarti, kai kyla iššūkis jų nacionaliniams interesams.

Analizuojant Lisabonos sutarties poveikị valstybių narių konsensuso galimybėms BUSP klausimais, negalima pamiršti šioje sutartyje įtvirtintų lojalumo ir bendradarbiavimo principu, kurie turètų užtikrinti valstybių narių lojalumą apskritai ES politikai. Lisabonos sutartyje yra numatyta nuostata, kad valstybės narés ịpareigoja laikytis EVT ir Užsienio reikalų tarybos nusistatytu pozicijų ir savo veikloje jomis vadovautis. ${ }^{64}$ Joje taip pat numatyti sisteminio bendradarbiavimo ${ }^{65}$ ir lojalaus bendradarbiavimo $0^{66}$ principai pabrëžia ir sustiprina valstybès narès įsipareigojimą vykdyti savo nacionalinę užsienio politiką, neprieštaraujančią Sajungos vykdomai užsienio ir saugumo politikai.$^{67}$ Tačiau šiu principu igyvendinimas taip pat neišvengiamai susidurs su bendra BUSP problema -ịpareigojančių mechanizmų trūkumu. Lisabonos sutartis nenumato Europos Teisingumo Teismo jurisdikcijos BUSP srityje. ${ }^{68}$ Vienintelès valstybiu nariu „paklusimą" BUSP principams galinčios užtikrinti institucijos - Taryba ir $\mathrm{ESVI}^{69}$, tačiau arsenalas priemoniu, kurias pastarosios gali panaudoti prieš pažeidèjas, apsiriboja "gèdinimu ir kaltinimu“ (angl. shaming and blaming) ${ }^{70}$.

\footnotetext{
${ }^{62}$ Treaty of Lisbon, 38 article. Politiniam ir saugumo komitetui pirmininkauja Sajungos Vyriausiojo igaliotinio užsienio reikalams ir saugumo politikai atstovas. Šis komitetas stebi tarptautinę padetị bendrai užsienio ir saugumo politikai priklausančiose srityse ir Tarybos prašymu, ESVI prašymu ar savo iniciatyva pateikia Tarybai nuomones, prisideda prie politikos krypčių apibrèžimo; stebi sutartu politikos krypčiu igyvendinimą. Taip pat Politinis ir saugumo komitetas atlieka Petersbergo užduočių politinę kontrolę ir joms vadovauja.

${ }^{63}$ Wessels, p. 13.

${ }^{64}$ Treaty of Lisbon, 26 ir 28 articles.

${ }^{65}$ Sisteminio bendradarbiavimo principas žymi, kad valstybės narès EVT ir Taryboje viena su kita konsultuojasi visais bendro intereso užsienio ir saugumo politikos reikalais, siekdamos apibrèžti bendrą požiūrị. Prieš imdamasi bet kokio veiksmo tarptautinejje arenoje ar prieš prisiimdama bet kokị issipareigojimą, kuris gali turèti įtakos Sajungos interesams, kiekviena valstybė narè su kitomis tariasi EVT arba Taryboje (Treaty of Lisbon, 32 articles).

${ }^{66}$ Vadovaudamasi lojalaus bendradarbiavimo principu, Sajunga ir valstybès narès gerbia viena kitą ir viena kitai padeda vykdydamos iš sutarčiu kylančias užduotis (Treaty of Lisbon, 4.3 article).

${ }^{67}$ Schmidt J., p. 250.

${ }^{68}$ Treaty of Lisbon, 24.1 article.

${ }^{69}$ Treaty of Lisbon, 24.3 article.

${ }^{70}$ Schmidt J., p. 258 .
} 
Būtent dèl šios priežasties vyriausybès yra linkusios apeiti švelniuosius įsipareigojimus, nesusidurdamos su jokiomis sankcijomis, ir taip tapti "zuikiais" (angl. free-rider) arba vykdyti savarankišką užsienio politiką, nesuderintą nei su kitomis valstybèmis narèmis, nei su ES institucijomis.

Priemonių, igalinančių teisiškai suvaržyti valstybes, kai sprendimas jau priimtas, t.y. priversti jas laikytis įsipareigojimu, nẻra. Tačiau dar didesnė problema yra priversti valstybes nares susitarti. Vienas iš šios problemos sprendimo būdu - sprendimu prièmimo procedūros pagrindinèje sprendimu prièmimo institucijoje - Taryboje - pakeitimas: vietoj BSGP (išskyrus keletą išimtinių atvejų) taikomo vieningo balsavimo principo įvedant kvalifikuotos daugumos balsavimo principą. Lisabonos sutartis iš tiesų išplečia kvalifikuotos daugumos balsavimo principo taikymo galimybes 40 nauju politikos sričiu, kuriose anksčiau sprendimai būdavo priimami vienbalsiai (pavyzdžiui, prieglobsčio klausimai, imigracijos politika, policijos ir teisminio bendradarbiavimo baudžiamosiose bylose klausimai), tačiau vieningo balsavimo principas (išskyrus kai kuriuos procedūrinius klausimus) yra išlaikomas priimant sprendimus dèl mokesčiu, užsienio, gynybos ir socialinëje politikoje. ${ }^{71}$ BUSP ir BSGP yra atkartojamos ankstesnèse sutartyse įtvirtintos vieningo balsavimo normos, kaip ir pabrèžiamas faktas, jog ES įstatymų leidyba šioje srityje yra netaikoma. ${ }^{72}$ Vieningo balsavimo principas gynybos klausimuose įtvirtinamas teigiant, kad sprendimai, susiję su bendra saugumo ir gynybos politika, taip pat sprendimai dèl misijų yra priimami Taryboje vienbalsiai, kai pasiūlymą pateikia vyriausiasis igaliotinis arba inicijuoja valstybès narès. ${ }^{73} \mathrm{ES}$ institucijos negali ipareigoti valstybių dalyvauti misijose ar operacijose, valstybés narès pasilieka teisę nedalyvauti operacijose, ypač jei jos jau ir taip yra daugianacionalinių pajègų dalis. ${ }^{74}$ Tiesa, Lisabonos sutartis numato išimčių tais atvejais, kai išsiskiria valstybiu narių nuomonės, tačiau egzistuoja keleto valstybių stipri politinė valia imtis iniciatyvų BUSP srityje. Pirma, Lisabonos sutartyje yra numatyta galimybe naudotis kvalifikuotos daugumos sprendimų prièmimo principu sudarant pradinį (angl. start-up) fondą ir inicijuojant nuolatinį struktūrizuotą bendradarbiavimą. ${ }^{75}$ Antra, sutartyje taip pat yra numatoma konstruktyvaus

\footnotetext{
${ }^{71}$ Gordon P. H., ,The Lisbon Treaty: Implications for the Future Relations between the EU and the US” Hearing before the subcommittee on Europe of the Committee on Foreign Affairs House of Representatives, $111^{\text {th }}$ Congress, First Session, December 15, 2009, p. 2 http://www.internationalrelations.house. gov/111/54133.pdf [žiūrèta $2010 \mathrm{~m}$. balandžio 28 d.]

${ }^{72}$ Quille G., ,The Lisbon Treaty and its Implication for CFSP/ESDP”. Directorate- General for External Policies, Policy Department, p. 3. http://www.luhan.ro/docs/Lisbon_Treaty_implications_CFSP_ ESDP_2009.pdf [žiūrèta $2010 \mathrm{~m}$. balandžio 20 d.]

${ }^{73}$ Quille G., p. 6.

${ }^{74}$ Witney N., ,Re-energising Europe’s Security and Defence Policy”. Policy Paper, 2008 July, European Council on Foreign Relations, p. 14.

${ }^{75}$ Treaty of Lisbon, 41.3; 46.2 articles.
} 
susilaikymo galimybè, kuri jau buvo įtvirtinta Nicos sutartyje ${ }^{76}$. Lisabonos sutartyje konstruktyvus susilaikymas reiškia tai, kad bet kuri balsuojant susilaikiusi Tarybos nare savo susilaikymą gali pateisinti padarydama oficialu pareiškimą: tokiu atveju ji nèra įpareigota taikyti sprendimo, bet pripažįsta, kad sprendimas įpareigoja Sajungą. ${ }^{77}$ Visgi būtina pripažinti, kad šios išimtys nèra pakankamos siekiant užtikrinti sprendimu priemimo BSGP srityje efektyvumą, o juo labiau - teisiškai igalinti ar įpareigoti valstybes laikytis priimtu sprendimu. Numatomi kvalifikuotos balsų daugumos taikymo sprendimu priemimo procese atvejai yra susiję su valstybių iniciatyvomis (sustiprintu bendradarbiavimu ir jo finansavimu), dèl kurių jau yra pasiektas konsensusas arba nepritariančios šalys, pasinaudodamos konstruktyvaus susilaikymo galimybe, neužkerta kelio iniciatyvos igyvendinimui.

Tai reiškia, kad nepaisant to, jog Lisabonos sutarties vienas pagrindiniu tikslų buvo užtikrinti BUSP efektyvumą, sprendimų priẻmimo neefektyvumo problema šioje ES politikoje lieka neišspręsta. Faktas, jog Lisabonos sutartyje BUSP bei BSGP ir vèl pavyko išvengti kvalifikuotos balsų daugumos sprendimu prièmimo taikymo signalizuoja, kad valstybėse narèse dar išlieka rimtų susilaikymų dèl bendros užsienio, saugumo ir gynybos politikos. Taigi akivaizdu, kad tokia susidariusi ir Lisabonos sutartimi įtvirtinta situacija vis dar neleidžia galutinai išspręsti sprendimų prièmimo efektyvumo problemos.

\section{Karinių pajègumų problema - ką žada struktūrizuotas bendradarbiavimas?}

Nors bendros užsienio ir saugumo politikos plètotè politiniu lygmeniu buvo vangi, ES valstybių narių bendradarbiavimas konkrečiose gynybos politikos iniciatyvose gerokai išaugo nuo dešimtojo dešimtmečio pradžios. ES valstybių karinès pajėgos dalyvavo bent keliose ES karinèse misijose įvairiuose pasaulio kraštuose, pradedant konfliktais Balkanuose, Pietų Kaukaze, baigiant Afrikos žemynu ir Artimaisiais Rytais. ${ }^{78}$ Lisabonos sutartyje yra numatyta, kad pagrindinis BSGP tikslas - užtikrinti Sajungos operaciniam veiksnumui reikalingus civilinius ir karinius pajėgumus, kuriais Sajunga gali naudotis vykdydama misijas, ${ }^{79}$ todèl ypač svarbus BSGP plètotès kontekste tampa pajėgumų klausimas. Europos Sajungos operacijų spektro plètra tiek ES sutartyse (Petersbergo užduočių apibrėžimo išplètimas), tiek praktiniame

\footnotetext{
${ }^{76}$ Konstruktyvaus susilaikymo principas balsuojant dèl iniciatyvų, kuriose šalis nepageidauja dalyvauti, garantuoja valstybei narei teisę susilaikyti neblokuojant sprendimo. Susilaikiusiujų skaičius neturi viršyti trečdalio. Art. 24 (3) treaty of Nice, Article 24(3). http://www.ecb.europa.eu/ecb/legal/pdf/en_nice.pdf [žiūrèta $2010 \mathrm{~m}$. balandžio $28 \mathrm{~d}$.]

${ }^{77}$ Treaty of Lisbon, 31 article.

${ }^{78}$ Overview of the missions and operations of the European Union September 2010. http://www.consilium.europa.eu/showPage.aspx?id=268\&lang=en [žiūrèta $2010 \mathrm{~m}$. balandžio $28 \mathrm{~d}$.]

${ }^{79}$ Treaty of Lisbon, 42 article.
} 
lygmenyje ịpareigoja valstybes nares lygiagrečiai plètoti turimus pajėgumus, siekiant gebèti vykdyti visas šitas operacijas.

\subsection{Gynybos pajégumų problematika}

Kariniai pajėgumai tuo pačiu metu yra ir pagrindinė BSGP plètotės ašis, ir silpnoji jos grandis. Iš esmės per daugiau nei dešimt ESGP gyvavimo metų Sajunga, nors ir sugebëjo teoriškai įvardyti pagrindines savo kariniu pajëgumų problemas ${ }^{80}$ bei numatyti modernizacijos ir pajëgumų plètotès gaires, nurodančias, kaip būtu galima jas spręsti (kelios pajėgumu planavimo konferencijos, Pagrindinis tikslas angl. Headline Goal) ${ }^{81}$, visgi nelabai pasistūmëjo spręsdama tas problemas praktiškai. Pagrindiniai iššūkiai, su kuriais susidūrė Sajunga, - nepakankamas finansavimas ir valstybių narių politinės valios rimtai kovoti su jų karinėse pajėgose įsišaknijusiomis problemomis trūkumas. Taigi ir šiandien Europos valstybės misijose geba panaudoti tik labai nedidelę dalị savo kariuomenių.

Be abejonės, galima kelti klausimą, ar ES apskritai reikalingi kariniai pajègumai. Galbūt savo misijoms ji turi plètoti civilinius pajègumus, o prireikus karinių priemonių - „,skolintis“ jas iš NATO. Tačiau verta nepamiršti fakto, kad dauguma ES valstybiu yra ir NATO narès, tad, kalbėdami apie ES kariniu pajègumų atsilikimą, lygiai taip pat turime kalbèti apie NATO europinio ramsčio kariniu pajėgumu atsilikimą. Todèl Europos valstybėms nesuskubus spręsti kariniu pajegumu problemos, realiai iškiltu priklausomybès ne nuo NATO, o nuo JAV iššūkis. Śiame kontekste svarbu ivertinti ir JAV karinio potencialo galimybes bei politinę valią imtis misiju, kurios yra svarbios Europos valstybėms, bet ne JAV. JAV dėmesys Europai po Antrojo pasaulinio karo bei šaltojo karo metais buvo nulemtas, kaip dažnai teigiama, tuo metu susiklosčiusios

\footnotetext{
${ }^{80}$ Skausmingiausiu karinių pajègumų silpnumo įrodymu tapo konfliktai tiesioginèje ES interesų zonoje Balkanuose. Kosovo konflikto metu ES susidūrè su dideliais sunkumais dẻl mobilumo, vadovavimo, kontrolès ir komunikacijos nepakankamo efektyvumo; konfliktai išryškino trūkumus strateginès žvalgybos palydovų, priešraketinès gynybos, strateginio oro transporto, tikslinio taikymo raketų bei kitos modernios technologijos srityse. Žr. Smith, I. D. (1999). Evidence from Shadow Secretary of State for Defense to the Committee on International Relations, $10^{\text {th }}$ November. United Kingdom House of Representatives. Pagaliau, net nebuvo skirtas pakankamas kiekis karinio personalo (nors ES dokumentuose egzistavo net $2 \mathrm{mln}$. pajègos, Europa sugebėjo išsiųsti tik 40 tūkstančių. Žr. Missiroli, A. (1999). Flexibility and Enhanced cooperation in European Security Matters: Assets or Liabilities. Occasional Paper,6. Paris: WEU Institute for Security Studies, 1999, p. 35. Kas tie „europiečiai“?

${ }^{81}$ Patvirtintas Pagrindinis tikslas (angl. Headline Goal) deklaravo, kad iki 2003 m. ES turi suformuoti pajègas (iki 15 brigadų: 50 000-60 000), kurios vykdytų Petersbergo užduotis, krizès rajone būtų išskleistos per 60 dienų ir sugebėtų ten veikti ne mažiau vienerių metų. Bendros pajègos veiktų tiktai krizės laikotarpiu, o ar skirti nacionalines karines pajègas ES valstybės spręstų savarankiškai. http://en.academic.ru/dic. nsf/enwiki/7068954 [žiūrèta $2010 \mathrm{~m}$. balandžio 28 d.]

Vèliau, 2004 m. gegužès mẻn., ES gynybos ministrai patvirtino naują planą - Pagrindinị tikslą 2010 (angl. Headline Goal 2010), skirtą ES karinių pajègumų formavimo procesui koreguoti atsižvelgiant i ankstesnio Pagrindinio tikslo metu iškilusias problemas ir naujus iššūkius. Headline Goal 2010. (2004). GAERC 17 May. http://ue.eu.int/uedocs/cmsUpload/2010\%20Headline\%20Goal.pdf [žiūrèta $2010 \mathrm{~m}$. balandžio 28 d.]
} 
strateginės aplinkos. Tuo tarpu šiandieninės tarptautinės sistemos pokyčiai verčia JAV kreipti savo interesus kitomis kryptimis. Nors JAV karinés išlaidos išlieka didžiausios pasaulyje, apie $46,5 \%{ }^{82}$ viso pasaulio karinių išlaidu, tačiau jos strateginiai ir politiniai interesai kinta kitų regionų naudai. Suprantama, kad JAV interesų kaita nusigręžiant ar „atsitraukiant" nuo Europos gali būti determinuojančiu ES politinès valios formavimosi veiksniu. Šiame kontekste ir antrasis klausimas, ar nevertètų ES apsiriboti civiliniais pajėgumais, atrodo nepagrįstas. Tačiau, kita vertus, civilinių pajėgumu, panaudojamų tarptautinėse misijose, klausimas yra ne mažiau komplikuotas nei karinių. Visų pirma todèl, kad jų ES neturi pakankamai, o antra, yra problemiška panaudoti šiuos pajègumus tiek dèl civilinių misijų pobūdžio, tiek dèl nepakankamo ES institucinio pasirengimo šias misijas vykdyti. Taigi BSGP ateitis neišvengiamai priklausys nuo ES valstybių gebejjimo plètoti reikiamus karinius pajègumus ir spręsti pajėgumų neefektyvumo problemas.

\subsection{Bendrụ gynybos pajègumų problematika}

Kariniu pajėgumų modernizavimas ir plètotè daug kainuoja, o viena pagrindinių ES visuomenių problema yra tai, kad Europos valstybiu gyventojai nèra pasirengę brangiai mokèti už savo saugumą, jiems daug aktualesni socialinès bei ekonominès gerovès klausimai. Šios nuostatos nulèmė tai, kad ES valstybių kariniai biudžetai jau kurị laiką mažèja. Pasaulį apėmus ekonominei krizei, gynybos išlaidu problema tampa dar aktualesnè. ${ }^{83}$ Kai kurios ES narès drastiškai mažina gynybos išlaidas: „Economist“ 2010 m. vasarą tvirtino, kad gynybos išlaidų klausimas artimiausiais metais bus dar opesnis, o dauguma šalių bus priverstos atsisakyti tam tikrų pajègumų. Kaip pavyzdžiai buvo pateikiami Olandijos ir Danijos atvejai, kai šalys turejjo atsisakyti brangiai kainuojančių projektų (Olandija - jūros žvalgybos, Danija - povandeninių laivų). ${ }^{84}$ Dar didesnio masto nepakankamo gynybos sektoriaus finansavimo problemos kamuoja Vidurio ir Rytų Europos valstybes, kurioms krizė smogè skaudžiau negu daugumai ES senbuvių. 2009 m. Bulgarija savo gynybos išlaidas sumažino 7,6, atitinkamai Kroatija - 8,3, Estija - 9,1, Lietuva - 11, Rumunija - 13, Slovakija $-6,7 \%{ }^{85}$ Suprantama, jog mažinant valstybès išlaidas daugumoje Europos valstybių visuomenėje mažai populiarūs gynybos biudžetai gali nukentèti dar daugiau negu kiti.

\footnotetext{
${ }^{82}$ Global Distribution of Military Expenditure 2009, http://www.globalissues.org/article/75/world-military-spending [žiūrèta $2010 \mathrm{~m}$. balandžio 29 d.]

83 Biscop S., Coelmont J., „Permanent Structured Cooperation: in defence of the obvious”, ISS. p.1. http://www.iss.europa.eu/uploads/media/Permanent_structured_cooperation_01.pdf [žiūrèta $2010 \mathrm{~m}$. liepos 12 d.]

${ }^{84}$ „Defence spending in a time of austerity“, The Economist. 2010 August 26. http://www.economist.com/ node/16886851 [žiūrèta $2010 \mathrm{~m}$. rugsèjo $2 \mathrm{~d}$.]

${ }^{85}$ „The global financial crisis and its impact on defence budgets“. http://www.nato-pa.int/default. asp?SHORTCUT=1928 [žiūrèta $2010 \mathrm{~m}$. rugsèjo 2 d.]
} 
Vis dèlto nevertètų pamiršti, kad bendra ES valstybių išleidžiama gynybai suma yra gana įspūdinga.$^{86} \mathrm{Ji}$ sudaro truputị mažiau nei pusę JAV gynybos biudžeto ir tai leidžia ES pagal gynybos išlaidas užimti garbingą antrą vietą tarp daugiausiai gynybai išleidžiančiu pasaulio valstybių. ES bendras gynybos biudžetas yra lygus šiame sąraše aštuonių po jos esančių valstybių biudžetu sumai. Tai verčia daryti prielaidą, kad pagrindinė ES gynybos pajėgumu finansavimo problema yra ne nepakankamas finansavimas, o netinkamas ir neefektyvus išteklių panaudojimas. Tam, kad europiečiai tai suvoktu, nereikejjo nei ekonominės krizės ${ }^{87}$. S. Biscopas yra ịsitikinęs, kad valstybės narės išleidžia per dideles sumas pinigų nereikalingiems ịsigijimams ir pajègumams ${ }^{88}$ Trukdžiai efektyviam ES valstybiu gynybos išlaidų naudojimui kyla tiek valstybiu viduje (netinkamas išlaidu paskirstymas, pasenusiu ginkluotės sistemų išlaikymas, per didelès išlaidos žmogiškiesiems ištekliams išlaikyti, mažai išlaidu, skirtų tyrimams), tiek ES mastu, kai išlaidos yra švaistomos dèl to, kad reikia finansuoti 27 skirtingas valstybių narių kariuomenes, turinčias savo tikslus, interesus ir planuojančias gynybos pajègumus atskirai.

Vienas iš galimų neefektyvaus gynybos išlaidu panaudojimo problemos sprendimų - masto ekonomija. Pasirinkus šį kelią ir pripažinus bei įvertinus svarbiausius ES karinių pajëgumų trūkumus, subūrus pajègiausiujų šalių koalicijas jiems šalinti, būtų imtasi bendros ES mastu karinių pajègumų reformos. Nors šis principas puikiai veikia ekonomikoje, deja, skamba gana utopiškai, kai kalbama apie valstybes ir jų karinius pajègumus. Bet kurie, net patys mažiausi, bendri tarptautiniai karinių pajègumų plètotés projektai dažnai tampa dalyvaujančių valstybių politinių žaidimu ịkaitais. Visgi valstybių koaliciju, galinčiu glaudžiau integruotis kurioje nors srityje, paliekant galimybę kitoms valstybėms jas pasivyti, idèja šiuo metu yra dažnai eskaluojama, tačiau ES darbotvarkëjeji nėra nauja. Diskusiju apie įvairias glaudesnio bendradarbiavimo formas tarp keliu šaliu, geriau pasirengusių bei norinčiu tai daryti BUSP srityje, būta ir anksčiau (, avangardo grupe $\dot{e}^{\prime}$, „Europos šerdis“ ar ",svorio centras") ${ }^{89}$ Verta pažymèti, kad pati glaudesnio bendradarbiavimo idèja apima ne tik BUSP, bet ir kitas ES politikos kryptis bei sritis, pavyzdžiui, mokesčiu politiką ir pan. Tačiau dèl BUSP plètotès sąstingio glaudesnio bendradarbiavimo galimybẻ matoma kaip ypač svarbus tos plètotès spartinimo elementas. Glaudesnio bendradarbiavimo principas pirmą kartą buvo paminètas Mastrichto sutartyje ${ }^{90}$,

\footnotetext{
${ }^{86}$ European Union Military budget 2009: 289 mlrd. dol. „US Defence secretary Robert Gates: Low EU \& NATO military spending“". 2010 February 26. http://www.nowpublic.com/world/us-defense-secretaryrobert-gates-low-eu-nato-military-spending [žiūrèta $2010 \mathrm{~m}$. rugsèjo $2 \mathrm{~d}$.]

${ }^{87}$ Missiroli, A. „Euros for ESDP: Financing EU Operations”, Occasional Paper, 45. Paris: EU Institute for Security Studies, 2003.

${ }^{88}$ Biscop S., Coelmont J., p. 3.

${ }^{89}$ Wolfgang Wessels and Franziska Bopp, ,,The Institutional Architecture of CFSP after the Lisbon Treaty- Constitutional breakthrough or challenges ahead?". Challenge. Liberty \& Security. Research Paper No. 10, June 2008. 26 p. Fischer, Joschka (2001), "Vom Staatenbund zur Föderation - Gedanken über die Finalität der Europäischen Integration”, Speech at the Humboldt Universität Berlin, 12 May.

${ }^{90}$ EMU and Social Charter, The Maastricht Treaty.
} 
vèliau patvirtintas Amsterdamo sutartyje $\mathrm{e}^{91}$, o Nicos sutartimi ${ }^{92}$ perkeliamas ir į BUSP. Viena iš glaudesnio bendradarbiavimo formų - nuolatinis struktūrizuotas bendradarbiavimas, net keletą kartų minimas Lisabonos sutartyje. ${ }^{93}$ Ir nors pats principo apibrèžimas ir taikymo sąlygos yra gana neblogai išplètoti Lisabonos sutartyje, kol kas tebevyksta diskusijos dèl šio principo taikymo bei dèl kriterijų glaudesniam bendradarbiavimui nustatymo. Vienas iš pagrindiniu tokio bendradarbiavimo uždavinių - sudaryti galimybes proveržiui BSGP dèl masto ekonomijos ir koordinuoto bendradarbiavimo bent iš dalies išsprendžiant nepakankamų pajègumų problemą.

\subsection{Nuolatinis struktūrizuotas bendradarbiavimas}

Vienas svarbiausių postūmių naujam glaudesnio bendradarbiavimo pasiūlymui buvo vadinamasis „,̌̌okoladinis vadovų susitikimas “94, kurio dalyviai tikejjosi tapti ESGP varomaja jèga. Susitikimo pabaigoje šalys išplatino pranešimą, kuriame pateikè pasiūlymus naujajai ES Konstitucijai. Šalia kitu pasiūlymų (solidarumo, kolektyvinès gynybos, Petersbergo misijų išplètimo, gynybos agentūros, atskiro nuo NATO ES valstybių narių gynybos štabo) buvo siūloma ES Konstitucijoje įrašyti struktūrizuoto bendradarbiavimo principą, sudaranti sąlygas norinčioms ir galinčioms valstybėms glaudžiau bendradarbiauti gynybos srityje, pasinaudojant ES institucinėmis struktūromis. Iš pradžių buvo svarstoma, kad šią avangardo grupę turètų sudaryti susitikime dalyvavusios valstybės, tačiau po kurio laiko tapo akivaizdu, kad joks progresas ESGP yra neįmanomas be Jungtinès Karalystės. Prancūzijos parlamentaras Pierre’as Lellouche'as pasiūlè, kad tokia avangardo grupe turètuc tapti didžiosios Europos šalys (Prancūzija, Vokietija, Italija, Ispanija, Lenkija ir Jungtinė Karalystė). ${ }^{95}$ Pasiūlymas sukurti avangardo grupę gynybos reikaluose sukèlè diskusijų audrą. Didžiausios šios iniciatyvos priešininkès buvo Jungtinė Karalyste ir VRE valstybės. Kritika buvo susijusi su „kelių greičių“ Europos sukūrimo pavojais ir galimybe sukelti skilimą ES.

Nepaisant audringu diskusiju, struktūrizuoto bendradarbiavimo galimybė vis dėlto buvo įtvirtinta Lisabonos sutarties 42 straipsnyje:

\footnotetext{
${ }^{91}$ The Treaty of Amsterdam, Article J7.4.

92 Treaty of Nice, Art. 17.4.

${ }^{93}$ Treaty of Lisbon, 42.6 article.

${ }^{94} 2003$ m. balandžio 29 d. Briuselyje įvykęs keturių ES narių vadovų susitikimas (Prancūzijos, Vokietijos, Belgijos ir Liuksemburgo) dèl bendradarbiavimo gynybos srityje. Meeting of the Heads of State and Government of Germany, France, Luxembourg and Belgium on European Defence, Brussels, 29 April 2003, http://www.euractiv.com/en/security/mini-summit-eu-defence-29-april-brussels/article-116091 [žiūrèta 2010 m. gegužès 5 d.]

${ }^{95}$ Witney N., „,Re-energising Europe's Security and Defence Policy”. Policy Paper, 2008 July, European Council on Foreign Relations, p. 15.
} 
Nuolatinis struktūrizuotas bendradarbiavimas remiasi prielaida, kad jị įgyvendins valstybės narès, kurių kariniai pajėgumai atitinka aukštesnius kriterijus ir kurios tarpusavyje yra susaistytos didesnių įsipareigojimų šioje srityje. ${ }^{96}$

Taigi valstybėms, gebančioms ir norinčioms aktyviau plètoti bendrus pajėgumus ES struktūrose, buvo uždegta žalia šviesa, kartu neverčiant prie šios iniciatyvos jungtis tų valstybiu, kurios nèra tam pasirengusios arba nenori to daryti.

Lisabonos sutartyje taip pat yra numatomi kriterijai, kuriais remiantis šalys galès jungtis ị grupes, siekdamos plètoti bendrus pajėgumus, t.y. ne vẻliau kaip iki 2010 m. valstybės įsipareigoja būti pajègios nacionaliniu lygiu arba kaip daugiašalių pajègu grupių sudedamoji dalis teikti specializuotus kovinius vienetus. ${ }^{97}$ Siekdamos šiu tikslų, nuolatiniame struktūrizuotame bendradarbiavime dalyvaujančios valstybès narès įsipareigoja:

- bendradarbiauti, siekdamos patvirtintų tikslų dėl išlaidų gynybos investiciju srityje;

- kuo labiau tarpusavyje suderinti gynybos mechanizmus;

- imtis konkrečiu priemonių savo pajègoms geriau panaudoti, jų tarpusavio sąveikai, lankstumui ir dislokavimo galimybems didinti, bendradarbiavimui plèsti, kad užtikrintų reikalingų priemonių „Gebẻjimų plètotès mechanizme" pastebėtiems trūkumams šalinti (įskaitant daugiašalius sprendimo būdus) taikymą, nepažeidžiant šiuo atžvilgiu Šiaurès Atlanto sutarties organizacijos sistemoje prisiimtų įsipareigojimų;

- prireikus dalyvauti plètojant pagrindines bendras ar Europos apginklavimo programas Europos gynybos agentūros struktūroje. ${ }^{98}$

Taigi nuolatinis struktūrizuotas bendradarbiavimas sudaro sąlygas jame dalyvaujančioms valstybėms efektyviau naudoti savo gynybos biudžetus ir diversifikuoti išlaidas. O prielaidos jungtiniams įsigijimo projektams, daugiašalių projektų kūrimui, mokslo ir tyrimų projektams padeda padidinti biudžeto dalį, tenkančią mokslui ir tyrimams. Pagal Lisabonos sutartį pirmą kartą valstybės narès sutinka su didesniais Europos gynybos agentūros ${ }^{99}$ igaliojimais. Pastaroji ne tik prižiūrètų įsipareigojimų vykdymą bei bendru projektų eigą, bet ir dalyvautų karinių pajégumų standartizacijos procese bei mokymuose. Sutartyje dar kartą pabrěžiama, kad bet kokia pajègumų plètotė turètų būti suderinama su valstybiu narių įsipareigojimais NATO, todèl, atsižvelgiant i šio principo taikymą praktikoje, struktūrizuotas bendradarbiavimas gali būti patrauklus ir toms valstybėms, kurios gynybos klausimais prioritetą teikia NATO, o ne ES.

\footnotetext{
${ }^{96}$ Treaty of Lisbon, 42 article.

${ }^{97}$ Treaty of Lisbon, Protocol No. 10, 1 article.

${ }_{98}$ Treaty of Lisbon, Protocol No. 10, 2 article.

${ }^{99}$ Europos gynybos agentūra buvo įsteigta bendru Ministrų Tarybos ir ET sutarimu $2004 \mathrm{~m}$. ir dabar yra itraukiama į Sutarti - stiprins karinių veiksmų pajėgumus (42(3) str.). 2003 m. Europos Taryba Graikijos Salonikų mieste išreiškè norą suformuoti tarpvyriausybinę gynybos pajègumų vystymo, tyrimų, i̇sigijimų ir ginklavimosi agentūrą. Dalyvauti joje gali norinčios šalys (visos, išskyrus Daniją). Bendriems projektams gali būti kuriamos specialios valstybių grupès.
} 
Nepaisant gražios struktūrizuoto bendradarbiavimo idejjos, įtvirtintos Lisabonos sutartimi, šio principo taikymas praktikoje išlieka miglotas. Verta prisiminti, kad $1991 \mathrm{~m}$. Mastrichto sutartyje įtvirtinto principo teikiamomis galimybèmis pirmą kartą praktiškai buvo pasinaudota tik $2010 \mathrm{~m}$. liepos mènesi, kada susituokusioms skirtingų tautybių poroms buvo nuspręsta leisti pasirinkti, kurios šalies įstatymai būtų taikomi jų skyrybų byloje. ${ }^{100}$ Net šioje srityje, nesusijusioje su politiškai jautriais vadinamajai "Didžiajai politikai“ priklausančiais klausimais, valstybėms narèms labai sunkiai sekèsi pasiekti susitarimą. Išryškèjo esminiai ES narių skirtumai, susiję su skirtinga kultūra bei komplikuojantys principo taikymą. Galimus politinės valios kaitos iššūkius puikiai pademonstravo Graikijos patirtis. Graikija prisijungè prie ši principą norinčių taikyti valstybių pirminiame etape, tačiau, nepaisydama pirminiu įsipareigojimų, po rinkimų pasikeitus politinei vyriausybès sudèčiai, pasitraukè iš „norinčiuju koalicijos“. Atsižvelgiant į tai, kad gynybos sritis yra platesnè ir politiškai jautresnė, galima tik įsivaizduoti, kokių rimtų iššūkiu gali sukelti skirtingi valstybių interesai. Nors nuolatinis struktūrizuotas bendradarbiavimas sudaro sąlygas išspręsti neefektyvaus išlaidų naudojimo bei galimai nepakankamų pajègumu problemas, jis paliečia tokius valstybėms narèms jautrius klausimus, kaip nacionalinis saugumas, nacionalinès karinės pajègos, gynybos planavimas. Kita vertus, vienos iš dalyvaujančiujuc šalių pozicijos pasikeitimas jau projektui prasidëjus gali sužlugdyti konkrečius pajègumų vystymo projektus ir atnešti didelių nuostolių kitoms projekte dalyvaujančioms valstybėms.

Ar užteks ES narèms politinės valios dèl efektyvios BSGP atsisakyti savo suvereniu galiu šiose srityse? N. Witney yra įsitikinęs, kad nè viena valstybẻ narè nesutiks būti ,įtraukta“ i i konfliktą Briuselio nurodymu; kita vertus, jos taip pat nesutiks su tuo, kad Briuselis reguliuotu ju gynybos išlaidas. ${ }^{101}$ Tą puikiai įrodo šalių narių vangumas įsipareigojimų dèl pajègumų konferencijose skiriant pajègumus konkrečioms misijoms, kai valstybės narès neturi interesu šalyse, i i kurias numatoma tas pajègas siųsti. Ekonominės krizès ir mažejjančių gynybos biudžetų akivaizdoje nuolatinis struktūrizuotas bendradarbiavimas gali atrodyti patrauklus sprendimas, tačiau panašu, kad valstybės narès bus priverstos rinktis, ką jos brangina labiau - savo suverenias galias gynybos klausimais ar BSGP veiksnumą. Kita vertus, matoma ir pozityvių signalų, kai siekdamos sutaupyti valstybės narès bando ieškoti naujų galimybių bendradarbiauti. 2010 m. lapkričio 2 d. dvi daugiausia léšu gynybai skiriančios ir didžiausią karinị personalą turinčios ES valstybès - Jungtinė Karalystė ir Prancūzija - pasirašè paskutiniu metu beprecedentį bendradarbiavimo gynybos srityje susitarimą, kuris apima daugiau nei 40 sričių: abiejų šalių A400M transporto, aviacinių pajėgumų sujungimą, tyrimų ir technologijų bendrą vystymą, kariniu pilotų

\footnotetext{
$\overline{100}$ „A first in European Union history: enhanced cooperation to help international couples is in force“. http://europa.eu/rapid/pressReleasesAction.do?reference=IP/10/1035 [žiūrèta 2010 m. rugsèjo 2 d.] ${ }^{101}$ Witney N., p. 1.
} 
rengimą ir t.t. ${ }^{102}$ Tai sritys, kurios kartais gali būti laikomos mažiau politiškai jautriomis, tačiau kuriose bendradarbiavimas leistų daugiau sutaupyti. Ir nors ilgą laiką buvo dvejota dèl Pranzūcijos pasiryžimo bendradarbiauti su Jungtine Karalyste (turint omenyje ju išsiskyrusias pozicijas Irako karo atžvilgiu ir Prancūzijos koncentravimąsi ties Europa, o JK - ties strategine partneryste su JAV), susitarimas įvyko ir yra laikomas teigiamu poslinkiu imantis realiu veiksmų siekiant suformuoti bendrą ES karinių pajėgumų bazę. Visgi dažnai yra pabréžiama, kad valstybės, pasirašydamos sutartị, tik nori išvengti dubliavimo ir siekia didesnio bendradarbiavimo, tačiau neaukoja savo suvereniteto saugumo ir gynybos politikoje. Bet net ir laikantis tokio požiūrio tampa suprantama, kad dabar Europa atsiduria ties triju pasirinkimų riba. Kaip interviu teigia N. Witney, kitos ES šalys gali tiesiog pasiduoti, būti paskatintos imtis kokių nors veiksmu siekdamos neatsilikti, arba, kaip jis pažymi, jos gali tiesiog nieko nedaryti. ${ }^{103}$ Tačiau net ir pačiu pesimistiškiausiu atveju, kada kitos valstybès lieka nuošalyje ir nesiima jokių iniciatyvu, galima teigti, kad dviejų didžiausių ES kariniu galybių bendradarbiavimas ir sutarimas tik stiprins Sajungos karinį potencialą. N. Witney netgi teigia, kad mažesnis bendradarbiaujančiu valstybių skaičius yra geresnis variantas ir tai argumentuoja logiškai pagrįstu teiginiu: esant didesniam skaičiui valstybių veiksmai yra užgožiami kalbų ir derybų. ${ }^{104}$ Taigi Prancūzijos - Jungtinės Karalystès sutartis suteikia optimistiniu vilčių saugumo ir gynybos politikoje. Susitarimas žymi ne tik dviejų ES karinių galybių suformuotą konsensusą dẻl bendrų tikslų, tačiau jau ir realių veiksmu pradžią. Žinoma, radikalių ir esminių pokyčių greitai tikètis nereikia, tačiau pirmieji žingsniai žengti.

Bendradarbiavimo gynybos srityje pavyzdžių ES yra ir daugiau, tačiau šis ypač svarbus, nes įtraukia dvi didžiausias ir labiausiai besiskiriančias nuomones dẻl būsimos BSGP plètotès turinčias ES nares. Tai valstybès, kuriu nesutarimai ar susitaikymas lemdavo didžiausius poslinkius BSGP plètotès istorijoje. Suprantama, kad didžiuju ES valstybių - Jungtinès Karalystès ir Prancūzijos - glaudesnis bendradarbiavimas ateityje gali išsirutulioti į dar tvirtesnị sutarimą dèl bendrų tikslų saugumo politikoje. Esant pamatiniam konsensusui, prie pastovaus šalių bloko galètu jungtis kitos ES galybės, pavyzdžiui Vokietija, ir taip tik dar labiau stiprinti bendradarbiavimą saugumo politikoje. Taigi svarbi tampa Lisabonos sutarties skiltis, ictvirtinanti sustiprinto bendradarbiavimo inicijavimo procedūrą. Skirtingai nuo kitų glaudesnio bendradarbiavimo formų inicijavimo mechanizmo, nuolatinio struktūrizuoto bendradarbiavimo atveju steigimo prašymas turi būti pateikiamas Tarybai ir

\footnotetext{
${ }^{102}$ Edward Cody, „France, Britain sign treaties calling for unprecedent military cooperation“. The Washington post foreign service, November 2, 2010. http://www.washingtonpost.com/wp-dyn/content/ article/2010/11/02/AR2010110203390.html [žiūrèta $2011 \mathrm{~m}$. sausio 10 d.]

${ }^{103}$ Kevin Beck, „British - French defence pact could prove way ahead“, Interview with Nick Witney, senior policy fellow at European Counsil on Foreign relations. Europolitics, No. 4093, November 30, 2010 , p. 8-9.

${ }^{104}$ Kevin Beck, „Interview with Nick Witney, senior policy fellow at European Counsil on Foreign relations", p. 8 .
} 
vyriausiajam igaliotiniui užsienio reikalams ir saugumo politikai (o ne Komisijai). Sprendimą dèl nuolatinio struktūrizuoto bendradarbiavimo pradžios Taryba, pasikonsultavusi su ESVI, priima kvalifikuota balsų dauguma. ${ }^{105}$ Ši procedūra sudaro sąlygas pakankamai lanksčiai pradèti ir vykdyti struktūrizuotą bendradarbiavimą. Tačiau detaliau, kaip struktūrizuotas bendradarbiavimas turètų būti įgyvendinamas, kokiais kriterijais remiantis valstybės galètų jungtis į glaudesnio bendradarbiavimo struktūras, Lisabonos sutartis nenumato. Todèl panašu, kad realiai šio principo igyvendinimą lems "gyvoji praktika“, kokị turinị į Lisabonos sutartimi pateikiamas gaires sudès valstybès narès. Šios Lisabonos sutartimi siūlomos naujovès apibrěžimu savo pirmininkavimo metu itin rūpinosi Belgija, organizuodama įvairius politikos formuotojų seminarus bei skatindama akademines diskusijas šiuo klausimu.

Belgijos smegenų centro „Egmont" parengta trumpa studija dèl nuolatinio struktūrizuoto bendradarbiavimo įgyvendinimo ${ }^{106}$ tapo aštrių politinių ir akademinių diskusijų objektu. Šio teksto autorius S. Biscopas tvirtina, kad, visų pirma, siekdamos bendrai kovoti su esamais pajègumų trūkumais valstybès narès turi sušaukti įsipareigojimų dèl pajėgumų konferenciją, kurios tikslas ištaisyti nustatytus trūkumus iki numatytos datos. Priemonės, kurių turi imtis valstybės: peržiūrèti nacionalini gynybos planavimą, atsisakyti nacionalinių pajègumu, kurie yra nereikalingi, sujungti lěšas ir pajėgumus skatinant taupymą, aktyviai bendradarbiauti siekiant bendru tikslų. ${ }^{107}$ Antra diskusinè tema, kurią siūlo S. Biscopas - kriterijai, kuriais remiantis valstybės narės jungsis ị šią glaudesnio bendradarbiavimo formą. Ši tema yra susijusi su platesnio pobūdžio diskusija, kilusia dar ginčijantis dèl nuolatinio struktūrizuoto bendradarbiavimo reikalingumo visu pirma Konstitucinèje, o vèliau - Lisabonos sutartyje. Pagrindinis diskusijų motyvas - prieštaravimas tarp selektyvaus ar visuotinio ịsitraukimo ị struktūrizuotą bendradarbiavimą, t.y. kaip išlaikyti struktūrizuoto bendradarbiavimo patrauklumą bei efektyvumą, kita vertus, kaip neatstumti norinčiu, bet duotu momentu nepajejgiu prisijungti valstybių.

Viena iš galimų struktūrizuoto bendradarbiavimo schemu - mažos avangardo šalių grupès, kurią sudarytų ES narès, skiriančios daugiausia išlaidu gynybai ir ginklavimosi programoms, sukūrimas, kada kitos valstybẻs atliktu tik antraeilį vaidmenị BSGP. Iš vienos pusės, toks paskirstymas lemtų efektyvesnę BSGP, tačiau, kita vertus, suskaidytų valstybes nares į dvi stovyklas: politiškai įtakingą avangardą ir realiai BSGP sprendimų prièmimo procese įtakos neturinčias likusiąsias. Nors Lisabonos sutartimi yra įtvirtinamas ,itraukiantis" (atviras ir siekiantis inkorporuoti kuo daugiau valstybiu narių) nuolatinio struktūrizuoto bendradarbiavimo principas, ${ }^{108}$ tačiau realiai struktūrizuoto bendradarbiavimo forma nèra apibrèžta, todèl vadinamoji

\footnotetext{
${ }^{105}$ Treaty of Lisbon, $46.1 ; 46.2$ articles.

${ }^{106}$ Biscop S. and Coelmont J., "Permanent Structured Cooperation in Defence of the Obvious". Security Policy Brief, No. 11, June 2010. http://www.egmontinstitute.be/papers/10/sec-gov/SPB-11_PSCD_II.pdf [žiūrèta $2010 \mathrm{~m}$. liepos $12 \mathrm{~d}$.]

${ }^{107}$ Biscop S. and Coelmont J., p. 2.

${ }^{108}$ Ten pat, p. 2.
} 
„gyvoji praktika“" priklausys nuo struktūrizuoto bendradarbiavimo ambiciju ir dalyvavimo kriteriju, kuriuos valstybės narès apsibrèš.

Svarbu suprasti, kad struktūrizuotas bendradarbiavimas nėra tikslas pats savaime, jo tikslas - išspręsti ES karinių pajègumų problemas. Tačiau norint tai pasiekti, galima pradèti nuo smulkesniujų elementų, susijusių su konkrečiomis priemonėmis. Pirmiausia būtina nustatyti svarbiausias pajègumų problemas ir su jomis susieti atitinkamas struktūrizuoto bendradarbiavimo sritis. Tačiau net ir tokiu atveju neįmanoma bus pabėgti nuo valstybių išsiskyrusiu ambiciju poveikio: kuriose srityse taikyti struktūrizuotą bendradarbiavimą, kokius projektus jis apims (pajėgumų kūrimą, apmokymą, įsigijimus, kokie yra jo tikslai ir pan.). Politikos formuotoju diskusijose apie struktūrizuoto bendradarbiavimo turinį dažnai yra keliamas klausimas - kuo jis skiriasi nuo jau egzistuojančių regioninių iniciatyvu, kurios gilina esamą integraciją arba sukuria naujas iniciatyvas, pavyzdžiui, Eurocorps, europinės oro transporto misijos $^{109}$, kovinès grupès ${ }^{110}$ ir panašiai. Net jeigu šią naujają struktūrizuoto bendradarbiavimo iniciatyvą laikysime dar viena pionierių grupe ${ }^{111}$, ilgalaikis jos tikslas vis tiek turi būti bendra ir ilgalaikè BSGP ar net BUSP strategija, kitaip tai teliks pavieniai ir trumpalaikiai projektai, kurie neišspręs struktūriniu karinių ES pajėgumų problemų.

Kitas, ne mažiau svarbus klausimas, susijęs su ambicijų lygiu, kurị teks valstybėms narėms išspręsti artimiausiu metu - dalyvavimo kriterijų klausimas. Mokslinio instituto „European Council on Foreign Relations" ekspertas Nickas Witney savo studijoje pateikia kelis pagrindinius kriterijus, kuriais remiantis turètų būti sudaromos struktūrizuoto bendradarbiavimo grupès: pakankamos gynybos išlaidos (matuojamos procentais nuo BNP); rimta karinių pajègų modernizacija, siekiant sukurti naudojamas pajėgas (matuojamas pagal investicijas ic kari); pasirengimas karines pajėgas naudoti (dalyvavimo operacijose procentas). ${ }^{112} \mathrm{~N}$. Witney pabrèžia, jog šie kriterijai bus reikšmingi tik tokiu atveju, kai bus atsižvelgiama ne į buvusią valstybiu patirti, bet i naujausius įsipareigojimus. Tačiau nustačius tokius gana aiškius kriterijus ir

\footnotetext{
109 Ten pat, p.3.

${ }^{110}$ Plačiau apie kovines grupes Lindstrom G. (2007). Enter the EU Battle Groups. Chaillot Paper, 97. Paris: EU Institute for Security Studies.

Mažų, mobilių kovos vienetų, gebančių greitai reaguoti i Europos krizes, projektas buvo pasiūlytas 2003 m. vasario 4 d. vykusiame Jungtinès Karalystès ir Prancūzijos vadovų susitikime Le Touquet. „Declaration on Strengthening European Co - operation on Security and Defence". (2003). 2004 m. birželio 16 d. EVT pritarè jų steigimui. Headline goal 2010. (2004). doc. 6309/6/04/REV6. Brussels: Council of the European Union. Vieną ,kovinę grupę“ turi sudaryti 1500 karių, kurie geba dalyvauti konfliktuose už ES ribų. Šių grupių užduotis - greitai (per 5-10 dienų, po daugiausiai 5 dienas trunkančio sprendimų prièmimo proceso) nuvykti ị konflikto regioną ir užtikrinti stabilią padėti jame tol, kol atvyks didesnès pajėgos (JT taikdariai ar kitos organizacijos). Kiekviena kovinė grupė galètų būti išskleista per 30 d. ES turi būti pasirengusi išskleisti vienu metu dvi kovines grupes 6000 spinduliu aplink Briuseli.. „Declaration on European Military Capabilities". (2004). Military Capability Commitment Conference, 22 November. Brussels.

${ }^{111}$ Kalbant apie pionieriu grupę, referuojama į iniciatyvos ar naujos vykdomos politikos valstybes- pradininkes. Plačiau žiūrèti - Witney N., p. 24.

${ }^{112}$ Witney N., p. 1.
} 
vèl bus susiduriama su ,itraukimo“ iššūkiu. Kiek valstybių narių atitiks šiuos kriterijus? Pavyzdžiui, net nustačius minimalų vieno procento gynybos išlaidų kriteriju (skaičiuojant nuo BNP), tokios šalys, kaip Austrija, Airija, Liuksemburgas ir Malta negalètų dalyvauti struktūrizuotame bendradarbiavime ${ }^{113}$. Ta pati lemtis ištiktų ir Bulgariją, Kiprą bei Graikiją, jei dalyvavimo operacijose riba būtų pasirinktas minimalus vieno procento kriterijus. ${ }^{114}$ Kita vertus, ne visos kriterijus atitinkančios šalys gali turèti norą ar politinę valią tapti šio avangardo dalimi. Viena iš pajejgiausių gynybos srityje ES narių - Jungtinė Karalystè-labai skeptiškai vertina struktūrizuoto bendradarbiavimo galimybes. Netgi Prancūzija, aktyviai rèmusi šio principo įtraukimą į Lisabonos sutarti, pradėjo abejoti jo praktiniu igyvendinimu.

Taigi gana ambicingas Lisabonos sutartyje pasiūlytas ES karinių pajègumų problemų sprendimo būdas - nuolatinis struktūrizuotas bendradarbiavimas - veiks tik tuo atveju, jei valstybès narès turès pakankamai politinès valios suteikti jam realų turinị. Ekonominè krizè bei mažejjantys gynybos biudžetai ES atveria galimybes valstybėms narèms pradèti politines diskusijas dèl efektyvesnio išlaidų naudojimo. Tačiau norint, kad tos diskusijos baigtųsi konkrečiu rezultatu, valstybėms narėms reikės atsakyti į keletą klausimų. Pirma, ar jos yra pasirengusios dali savo suvereniu galiu gynybos srityje perleisti ES. Antra, kokia nuolatinio struktūrizuoto bendradarbiavimo forma - visa įtraukianti ar selektyvi, „iš viršaus į apačią“ ar „iš apačios į viršų“ - jas tenkina bei kokie dalyvavimo kriterijai turi būti taikomi. Jei valstybės narès pasirinks visa ittraukiančią bendradarbiavimo formą, jos pačios taps labiau varžomos savo sprendimų ir įsipareigojimu, taip pat gali nukentèti BSGP efektyvumas. Tuo tarpu selektyvus bendradarbiavimas gali supriešinti valstybes nares, paversti ES BSGP srityje dvinare sistema, kurioje vieni priiminès sprendimus ES vardu ir juos igyvendins, o kiti liks „didžiosios“ ES politikos užribiuose. Trečiasis klausimas, kokia bus struktūrizuoto bendradarbiavimo vieta bendroje ES strategijoje? Ir, pagaliau, ketvirtas klausimas, kaip struktūrizuotas bendradarbiavimas derès su nacionaliniais gynybos planavimo procesais bei gynybos planavimu NATO. Kol valstybės narès nesusitars dèl bendrų atsakymų į šiuos fundamentalius klausimus, labai sudètinga bus prognozuoti tiek nuolatinio struktūrizuoto bendradarbiavimo reikšmę BSGP, tiek pačios BSGP plètotès galimus scenarijus.

\section{ESGP karinių misijų finansavimo problema}

Nepakankamas ir neefektyvus ES valstybių finansavimas karinių pajègumu plètotei nèra vienintelis iššūkis šioje srityje. Ne mažiau opi operacinio lygmens problema - ES karinių misijų finansavimas. Administracinès ir ei-

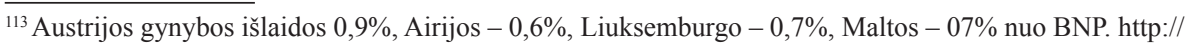
milexdata.sipri.org/ [žiūrèta $2010 \mathrm{~m}$. rugsèjo 2 d.]

${ }^{114}$ Witney N., p. 2.
} 
namosios ES misijų išlaidos, išskyrus karinėms ir gynybos operacijoms, yra įtraukiamos į Sajungos biudžetą. Operacijos, kurios neįtraukiamos į Sajungos biudžetą, yra finansuojamos iš valstybių narių lěšu (atitinkamai pagal jų BVP) pagal principa , išlaidos tenka tam, kas jas sukuria“. ${ }^{115}$ Tačiau šio principo naudojimas iš tiesų menkai motyvuoja valstybes dalyvauti karinėse operacijose, ypač kai jos pačios ir taip tuo tèra menkai suinteresuotos. Patirtis rodo, kad kiekvienos karinės operacijos atveju vyksta sudètingas pajėgumų formavimo procesas, kurio metu yra labai sunku įtikinti valstybes nares skirti kad ir nedidelius pajègumus. Išimtis, ko gero, būtų Prancūzija, kuri yra viena aktyviausių BSGP „,advokačių“ ES. Tačiau net ir ši valstybė daugumoje ES vykdytų karinių operacijų atveju turëjo tose šalyse nacionalinių interesų.

Nežiūrint įvairiais lygmenimis kylančių problemų, verta pripažinti, kad ES patirtis misijose jau dabar yra gana turtinga, o apimtis ir tikslai nuolatos auga (iki šiol vykdytos 25 ES civilinès ir karinès misijos) ${ }^{116}$. Tai leidžia teigti, kad tokių misiju poreikis yra ir, ko gero, ateityje tik didès. Kita vertus, plečiantis misijoms didejja ir problemos, su kuriomis valstybės narès susiduria organizuodamos šias misijas. Problemas galima suskirstyti į du pogrupius. Pirmasis - susijusios su operacijos pradžia, antrasis - susijusios su operacijos vykdymu. Pirmojo pogrupio problemos apima valstybių narių nesutarimus dèl to, ar verta pradèti vieną ar kitą misiją bei kokio pobūdžio ji turètų būti, žmogiškujų išteklių ir ginkluotès įsipareigojimų konkrečiai misijai ir misijų finansavimo klausimai. Pavyzdžiui, ES prireikè net šešių mėnesių surasti 16 malūnsparnių ir 10 lèktuvų misijai Čade. Antrojo pogrupio problemos taip pat svarbios ir susijusios su tokiais iššūkiais, kaip misijos mandato kaita, rotacijos klausimai ir t.t. Sėkmingos misijos yra neįmanomos be valstybių narių interesu konvergencijos ir politinès valios, o tai labai sudètinga užtikrinti tiek dèl ES bendros strateginès vizijos trūkumo bei valstybių narių interesų išsiskyrimo, tiek dẻl vieningumą užtikrinančio ir ipareigojančio institucinio mechanizmo, susijusio su misijų ígyvendinimu, nebuvimo.

Siekiant išspręsti bent dalị įvardytų problemu, Lisabonos sutartis pasiūlè svarbią naujovę - bendrą ES fondą daliai operacinių išlaidų padengti. Ši naujovè visu pirma skirta bent iš dalies spręsti pirmojo pogrupio problemoms, susijusioms su žmogiškaisiais ištekliais ir ginkluote bei finansiniais įsipareigojimais konkrečiai misijai. Jau 2004 m., kai buvo įdiegtas Athena mechanizmas, ${ }^{117}$ ES įsipareigojo bent dalį ES operacinių išlaidų padengti iš ES biudžeto - lauko štabams kurti bei išlaikyti, kariniam personalui apgyvendinti ir transportuoti. Vis dèlto šis mechanizmas sudaro sąlygas padengti tik labai mažą dalį operaci-

\footnotetext{
${ }^{115}$ NATO naudojamas karinių operacijų finansavimo principas, angl.costs lie where they fall.

${ }^{116}$ Dabar vykstančios misijų yra 14: 5 Europoje (2 Bosnijoje ir Hercegovinoje, 1 Moldovoje ir Ukrainoje, 1 Kosove, 1 Gruzijoje), 5 Afrikoje (po 2 misijas Konge ir Somalyje ir 1 Libijoje) ir 4 Azijoje (Irake, Gazoje, Palestinoje ir Afganistane). Baigtu misijų yra 11: 4 Europoje (1 Gruzijoje ir 3 buvusioje Jugoslavijos Respublikoje Makedonijoje), 6 Afrikoje (3 Kongo DR, 1 C̆ade, 1 Naujoje Gvinèjoje ir Darfüre) ir 1 Indonezijoje.

${ }^{117}$ Visos šalys narès skiria pinigų sumą, susietą su jų BNP. http://www.consilium.europa.eu/uedocs/cmsUpload/Factsheet_Financing2.pdf [žiūrèta 2010 m. rugsèjo 2 d.]
} 
nių išlaidu, o likusi operacijų sukeliamu išlaidų dalis yra paliekama valstybiu narių finansų bei gynybos ministerijoms. Todèl iš esmès šis mechanizmas nesudaro galimybių valstybėms narėms dalytis operacinėmis išlaidomis. Negana to, Athena mechanizmas komplikuotas dar ir dèl to, kad kiekvienos misijos atveju sprendimai dèl išlaidų padengimo pagal ši mechanizmą yra svarstomi ministru lygmeniu bei priimami vienbalsiai. Tad kiekvienu atveju, kai yra nors viena konkrečia misija nesuinteresuota valstybė, ji gali užkirsti kelią net jau prasidejjusios misijos finansavimui. Tačiau net jei sutarimas yra pasiektas ES lygmeniu, tai nereiškia, kad jo bus laikomasi valstybėse narèse. Po derybu i savo gimtąsias valstybes grižę gynybos ministrai turi rimtai padirbèti, kad priimto sprendimo neišvengiamumu ir būtinumu įtikintų ir kitus vyriausybès narius ar parlamentarus. Politiškai jautrūs klausimai, tokie kaip papildomos gynybos išlaidos ar išlaidos karinėms operacijoms, visada igyja didelį atgarsị visuomeneje ir viešojoje erdvèje, todèl juos išspręsti tampa labai sudètinga. $\mathrm{O}$ vieningai nesutariant dèl gynybos išlaidų dydžio ir toliau yra susiduriama su operacijų finansavimo trūkumu.

Lisabonos sutartis numato naujovę ESGP karinių misijų finansavimo mechanizme, t.y. sukuria galimybę greitai paskirti finansavimą ES civilinėms ir karinems misijoms pasinaudojant "pradžios fondu“. ${ }^{118}$ Šis pradinis fondas būtų sudarytas iš valstybių narių įnašų, o ET spręstų jo sukūrimo būtinybès klausimą, administravimą bei kontrolę ir ipareigotų ESVI juo disponuoti naudojantis kvalifikuotos daugumos balsavimo procedūra. ${ }^{119}$ Taigi, viena vertus, šis biudžetas iš dalies yra išlaisvinamas nuo tiesioginės valstybių narių įtakos, antra vertus, jis taip pat nėra priklausomas nuo Sajungos biudžeto bei jo procedūrų. EP, kuris yra visada įtraukiamas į Sajungos biudžeto svarstymo ir tvirtinimo procedūrą, šiuo atveju tampa tik konsultaciniu organu. ${ }^{120}$ Šis ES karinių operacijų finansavimo mechanizmas sudaro sąlygas siųsti savo karines pajègas i misijas ir toms valstybėms, kurios nèra pajègios finansuoti savo karinių operaciju, taip pat sudaro sąlygas palengvinti išlaidų naštą toms, kurios tai pajègia. Tačiau kaip ir struktūrizuoto bendradarbiavimo atveju, kadangi visi su šiuo fondu siejami klausimai yra sprendžiami Taryboje, lieka neaišku, kiek valstybės narès bus nusiteikusios mokèti už karines misijas, kuriomis nèra suinteresuotos. Mažejjantys gynybos biudžetai gali sukelti rimtų iššūkių tokiam fondui steigti. Be to, dèl labai nevienodų valstybių narių įnašų į šį fondą, liktų neišspręsta neproporcingai didelio kai kurių valstybiu indèlio ị ES karines misijas problema. Todèl ir tolesnès šio fondo steigimo galimybès priklausys nuo valstybių narių suinteresuotumo.

\footnotetext{
118 Angl. Start-up fund.

${ }^{119}$ Treaty of Lisbon, 41.3 article.

${ }^{120}$ Wessels W., p. 12.
} 


\section{Išvados}

Lisabonos sutarties ratifikavimas po Konstitucinès sutarties žlugimo turëjo būti savotiška išeitis iš susidariusios pasitikèjimo Europos Sajunga ir joslegitimumo krizės. Su šiuo naujausiu ES dokumentu ypač dideli lūkesčiai buvo siejami bendros užsienio ir saugumo politikos srityje, kurioje buvo pasiūlyta daug naujovių. Kiekviena iš šių naujovių suteikia galimybių naujam požiūriui i BSGP, naujoms iniciatyvoms ir sudaro sąlygas pašalinti kai kurias ilgą laiką BSGP stagnaciją skatinusias problemas. Teisinio subjektiškumo įtvirtinimas leidžia bent jau teoriniu lygmeniu modeliuoti bendrą ir savarankišką ES užsienio ir saugumo politiką, neapsiribojančią vien valstybių narių užsienio politikų išvestine. Petersbergo užduočiu išplètimas ir įtvirtinimas teisiškai sudaro pagrindą įsivaizduoti, kokio pobūdžio misijos sudarys BSGP darbotvarkę ir atitinkamai planuoti pajègumus. Lisabonos sutartimi pasiūlyta nuolatinio struktūrizuoto bendradarbiavimo galimybė sudaro sąlygas plètojant ES karinius pajégumus ir naudojantis masto ekonomijos principu pašalinti nuolatinę neefektyvumo problemą bei sušvelninti nepakankamo finansavimo iššūkius. Solidarumo ir bendros gynybos sąlygos parodo, kad ES sugeba reaguoti į naujausius saugumo iššūkius ir kartu derinti skirtingus valstybių narių lūkesčius gynybos srityje. Apskritai Lisabonos sutartis sukuria daug galimybių valstybėms narėms bendradarbiauti gynybos srityje, kartu kurti efektyvią ES gynybos politiką. Tačiau tuo pat metu Lisabonos sutarties poveikiui BSGP srityje įvertinti galima puikiai pritaikyti žymiają Aleksandro Wendto frazę - ,, anarchija yra tai, ką valstybės iš jos sukuria"121. Visos Lisabonos sutartimi pasiūlytos naujovès priklausys nuo to, kokị turinį valstybès narès norès ir gebès sudèti i jos straipsnius ir kaip tai atsispindès "gyvojoje praktikoje“.

Atsiradus ES teisiniam subjektiškumui, valstybès narės išlaiko galimybę užkirsti kelią ateities pokyčiams, jei paaiškètu, kad tolesniems žingsniams neužteks politinès valios. Kita vertus, Petersbergo užduočių išplètimas bei teisinis įtvirtinimas, nors ir sveikintinas žingsnis, neveiks tol, kol ES neturès bendros užsienio ir saugumo politikos strategijos. Instituciniai pokyčiai iš dalies sprendžia menkos koordinacijos BSGP srityje problemas, bet daug kas priklausys tiek nuo asmeninių ESVI gebëjimu, tiek nuo valstybių narių valios ir noro susitarti Taryboje. Tad po Lisabonos sutarties išliekanti ịpareigojančiu mechanizmu priversti valstybes nares susitarti ir laikytis įsipareigojimų problema nesuteikia daug optimizmo. Ko gero, svarbiausia naujove galima būtu ivvardyti nuolatinio struktūrizuoto bendradarbiavimo principą, kuris mažejančių ES valstybių nariu gynybos biudžetu kontekste suteikia daug galimybiu racionalizuoti gynybos išlaidas ir užsitikrinti naudą visoms valstybėms narėms. Tačiau siekdamos imtis konkrečių veiksmų šioje srityje valstybės narẻs turès susitaikyti su gynybos politikos ir gynybos pajegumų planavimo išbraukimu iš išimtinai valstybių kompetencijai priklausančių sričių sąrašo bei susitarti

\footnotetext{
${ }^{121}$ Alexander Wendt, „Anarchy is what states make of it: the social construction of power politics”. International organization, 46, 2 Spring, 1992.
} 
dèl bendrų struktūrizuoto bendradarbiavimo organizavimo kriteriju. Žinoma, i̇manomas žingsnis „iš apačios“", apsiribojant jau veikiančiomis ir keletu nauju bendradarbiavimo gynybos srityje iniciatyvų (aptartas Prancūzijos - Jungtinès Karalystės pasirašytas bendradarbiavimo gynybos srityje susitarimas), tačiau ilgalaikejje perspektyvoje jis neišspręs pagrindinių ES valstybiu pajėgumu problemu ir net gali paskatinti „skilimą" tarp valstybių narių.

Solidarumo ir bendros gynybos sąlygų veikimas neišvengiamai priklausys nuo pajėgumu plètotės bei valstybių politinės valios ir pasimatys tik iškilus konkrečiam atvejui. Hipotetiškai įsivaizduoti solidarumo, o ypač bendros gynybos sąlygu taikymą praktikoje nẻra sunku, tai pagrindžiant pasikeitusia situacija arba netikètu įvykiu, inspiruojančiu ES valstybiu narių bendros valios apraiškas. Kaip vienus iš determinantų, skatinančių bendros politinės valios atsiradima, galima išskirti atsirandančią NATO krizę ar sunkejjančią ekonominę situaciją, JAV galimą „, atsitraukimą" nuo Europos, vis stiprẻjantį dvišalį Jungtinės Karalystės ir Prancūzijos bendradarbiavimą ar netikètą teroro aktą. Tačiau prognozuoti ir nuspèti galimą ES valstybiu narių sutarimą bendros gynybos klausimais remiantis vien tik hipotetine ir netiketa situacija neužtenka. Būtinas pamatinis ES narių sutarimas dèl bendru gynybos veiksmų. Tad atsakymas i klausimą, ar Lisabonos sutartis sprendžia gilumines BSGP problemas, gali būti redukuojamas ị teigini, kad Sutartis sudaro galimybes jas spręsti, tačiau tik tuo atveju, jei ES valstybės matys reikalą ir norès jas spręsti. Nauja ES, kaip tarptautinių santykių veikëjo, era bus nulemta to, kiek nuoširdi ir ilgalaikẻ yra valstybių narių politinè valia plètoti bendrą saugumo ir gynybos politiką.

2011 m. balandis 